\title{
Calixarene complexes with soft metal ions
}

\author{
Wanda Sliwa* and Malgorzata Deska \\ Institute of Chemistry and Environmental Protection, Jan Dlugosz University \\ al. Armii Krajowej 13/15, 42-201 Częstochowa, Poland \\ E-mail: w.sliwa@ajd.czest.pl
}

\begin{abstract}
In this review calixarene complexes with copper, silver, gold, zinc, cadmium and mercury ions are described, showing their properties and application possibilities. In some cases also resorcinarene and pyrogallolarene metal complexes are presented. The attention is paid to species interesting in the search of artificial enzymes.
\end{abstract}

Keywords: Calixarene, complex, guest, metal ion, pyrogallolarene, resorcinarene

\section{Table of Contents}

Introduction

1. Calixarene complexes with copper ions

2. Calixarene complexes with silver ions

3. Calixarene complexes with gold ions

4. Calixarene complexes with zinc ions

5. Calixarene complexes with cadmium ions

6. Calixarene complexes with mercury ions

Conclusions and future outlook

Acknowledgements

References

\section{Introduction}

Calixarenes, along with related compounds, i.e. resorcinarenes and pyrogallolarenes are metacyclophanes intensively studied due to their interesting properties; they may serve as receptors of ionic and neutral species ${ }^{1-3}$ and as building blocks of structures of supramolecular chemistry, for example as components of cavitands ${ }^{4-6}$, capsules ${ }^{4,7,8}$ and nanotubes. ${ }^{9,10}$ 
A great number of works dealing with calixarenes is a reflection of an increasing research in view of usefulness of these species, e.g. in the molecular recognition, ${ }^{11}$ separation procedures ${ }^{12-14}$ and as mimics of biological processes. ${ }^{15}$ Growing attention is paid today to calixarene complexes with metal ions; numerous calixarene complexes with alkali, ${ }^{16,17}$ alkaline earth ${ }^{12,18}$ and transition metal $^{19,20}$ ions are now a topic of an intense study. This rapidly developing area is investigated from the theoretical and practical viewpoint due to possible applications of such complexes as catalysts $^{21,22}$ as well as in the search for artificial enzymes, ${ }^{23}$ and in the design of sensors for determination of trace amounts of metal ions, ${ }^{24-26}$ especially in the aspect of the environment protection. ${ }^{27}$ One should point out the works on calixarene complexes with cesium ${ }^{28,29}$ as well as with lanthanides ${ }^{30,31}$ and actinides ${ }^{31,32}$ are aimed at management of nuclear waste materials.

The present review is connected with our former papers concerning calixarene dime-ric ${ }^{33}$ as well as trimeric and hexameric ${ }^{34}$ capsules, cavitands, ${ }^{35-37}$ inclusion complexes of calixarenes, ${ }^{38}$ heterocalixarenes, ${ }^{39}$ resorcinarenes, ${ }^{40}$ and calixpyrroles, ${ }^{41}$ and is a continuation of papers on calixarene complexes with transition metal ions. ${ }^{42,43}$ The references cited in the latter both articles describe research results in this field of chemistry; the area of our present paper covers more recent works. Since the amount of reports dealing with metal complexes of calixarenes is enormous, the selected examples of calixarene complexes with soft metal ions - copper, silver, gold, zinc, cadmium and mercury are described. The references are cited mainly of works that appeared during 2005-2007.

\section{Calixarene complexes with copper ions}

It is known that $\mathrm{Cu}^{2+}$ ion plays an important role in biological systems, however it is also a significant environmental pollutant; the detection and determination of this ion receives today growing attention. ${ }^{44}$ Many reports deal with calixarene copper complexes. ${ }^{45-50}$

In investigation of calixarenes 1-3 bearing $\beta$-ketoimine groups, it was shown that these functions enable their complexation with transition metal ions. Calixarenes 1-3 exist in a cone conformation in solution; with $\mathrm{Cu}^{2+}, \mathrm{Ag}^{+}$and $\mathrm{Hg}^{2+}$ ions they yield the $1: 1$ complexes. ${ }^{51}$ In the solid state "a polymeric linear chain" is formed as a result of intermolecular interactions between $\beta$-ketoimine groups.

The water-soluble calixarene 4, in which the 2,2'-bipyridine units show both hydrophilic and chelating properties, forms complexes with $\mathrm{Cu}^{+}$and $\mathrm{Cu}^{2+}$ ions. The aqueous solution of 4 treated with $\left[\mathrm{Cu}(\mathrm{MeCN})_{4}\right] \mathrm{PF}_{6}$ affords the $1: 1$ complex $\mathbf{C u}^{+} \cdot 4^{52}$ It should be pointed out that $\mathbf{C u}^{+} \cdot \mathbf{4}$ is very stable, even in the presence of bovine serum albumin and is promising for use in biological media.

The complexation properties of calixarenes 5 and $\mathbf{6}$ toward $\mathrm{Cu}^{2+}$ and $\mathrm{Zn}^{2+}$ ions have been investigated. ${ }^{53}$ The binding of 5 with metal ion $\mathrm{M}^{2+}\left(\mathrm{Cu}^{2+}\right.$ or $\left.\mathrm{Zn}^{2+}\right)$ is a two-step process, the first step involves the complexation of metal ions with imine functions affording 7 and the 
second one concerns the binding of two ether oxygen atoms of the pendants to give $\mathbf{8}$.

It was found that the spacer imine groups of 5 that are in conjugation with the anthryl units are responsible for fluorescence quenching when the metal ion is absent. In free $\mathbf{5}$ the imine group conjugated with the anthryl unit makes the system rigid; the lone electron pair is delocalized on the $\pi$-cloud of the anthracene unit. Due to this rigidity a favorable orbital overlap between the imine nitrogen atom and the $\pi$-orbital of anthracene exists, resulting in photoinduced electron transfer (PET) from imine nitrogen atom to the photoexcited anthryl unit. The presence of the conjugated imine moiety in $\mathbf{5}$ is responsible for the fluorescence quenching of the anthryl unit, since the photoinduced electron transfer (PET) from nitrogen atom of the imine group to the anthryl $\pi$-cloud exists.

The binding of the metal ion with imine groups destroys the effect of the lone pairs of nitrogen atoms which had caused the conjugation; therefore the PET is prevented and the fluorescence intensity increases. This fluorescence enhancement is stronger in $\mathbf{5}$ than in $\mathbf{6}$ where no imine moiety is present. It was found that $\mathbf{5}$ acts as a chemosensor for $\mathrm{Cu}^{2+}$; since the increase in the fluorescence intensity for $\mathrm{Cu}^{2+}$ is higher than for $\mathrm{Zn}^{2+}$, these both ions can be differentiated.

The chiral amphiphilic resorcinarene 9 containing four L-proline (Pro) moieties at the wide rim and four undecyl groups at the narrow rim has been synthesized. The molecules of 9 may self-assemble at the air-water interface as stable Langmuir monolayers. In the investigation of the effect of various cations on the stability of Langmuir monolayers it was found that their stability is highly increased in the presence of $\mathrm{Cu}^{2+}$ ions, while in the presence of $\mathrm{Cd}^{2+}, \mathrm{Co}^{2+}$ and $\mathrm{Ni}^{2+}$ ions only slight stabilization occurs. ${ }^{54}$

The supramolecular complex $\mathbf{C u}^{2+} \cdot \mathbf{9}$ shows enantioselective recognition properties towards phenylalanine (Phe), with a stronger affinity for D-Phe than for L-Phe. The recognition process occurs via the formation of a ternary complex $\mathbf{C u}^{2+} \cdot \mathbf{9} \cdot \mathbf{D}-\mathrm{Phe}$. In this complex the $\mathrm{Cu}^{2+}$ ion is chelated by two carboxylato oxygen atoms and by two nitrogen atoms of Pro and Phe, forming a planar square. ${ }^{54}$ The above results are promising for the use of macrocyclic receptors of the type of 9 as active layers in the design of enantioselective sensors. 

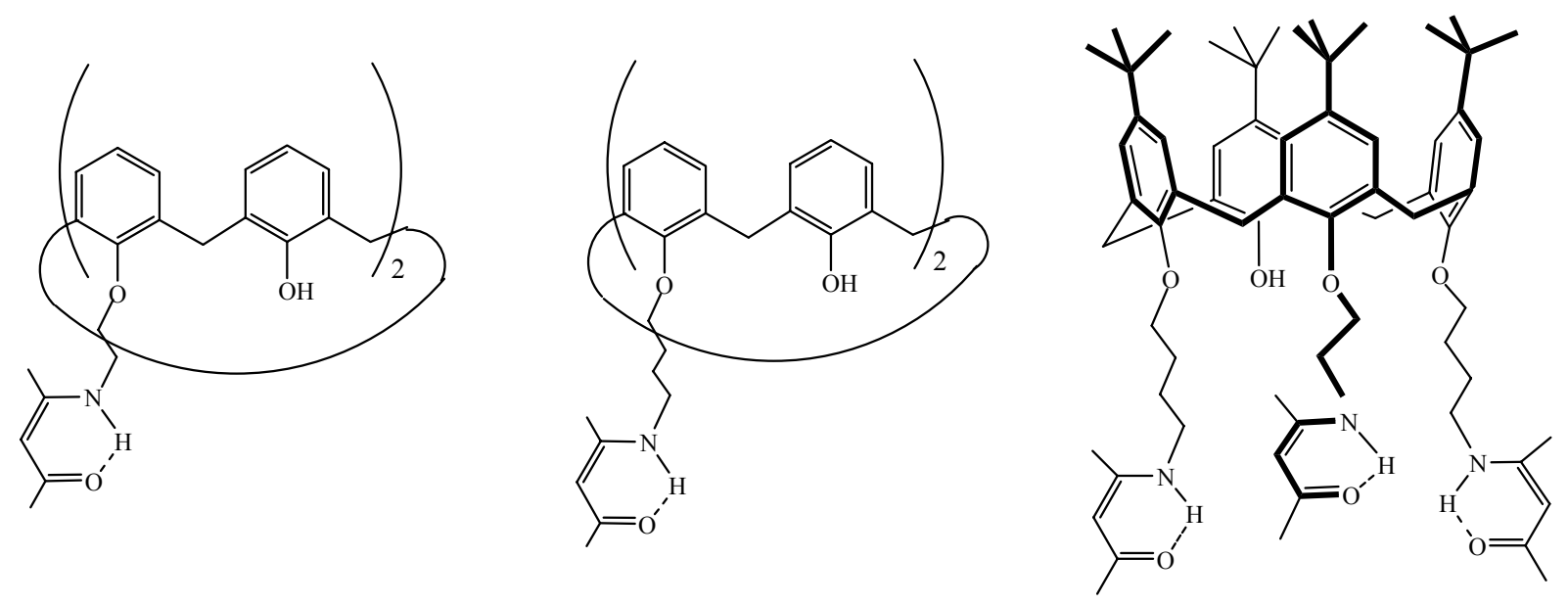

1

2

3
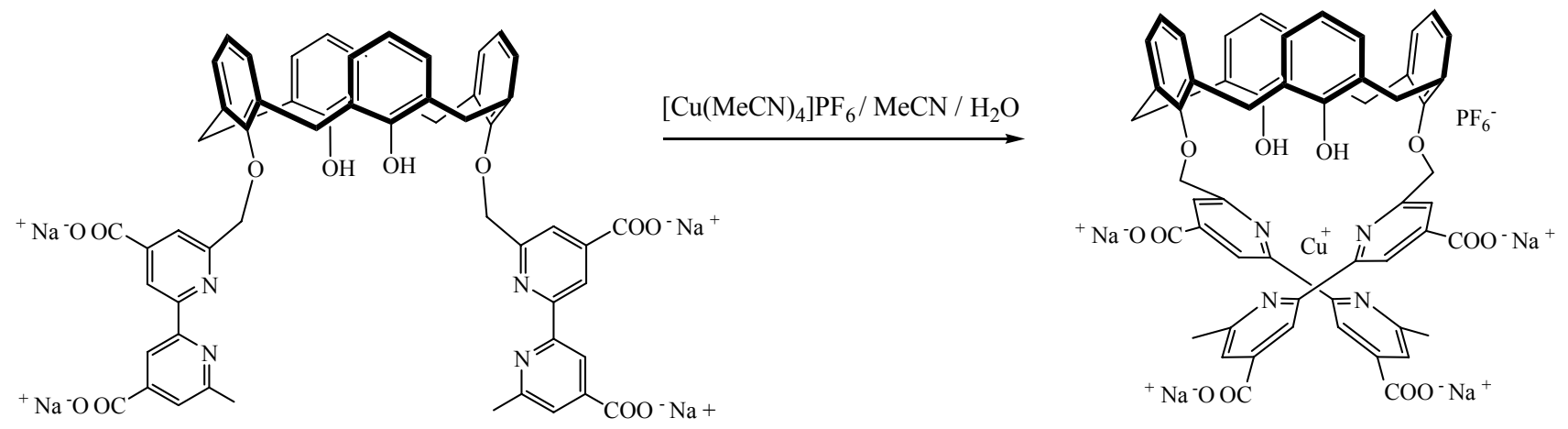

4

$\mathrm{Cu}^{+} \cdot 4$
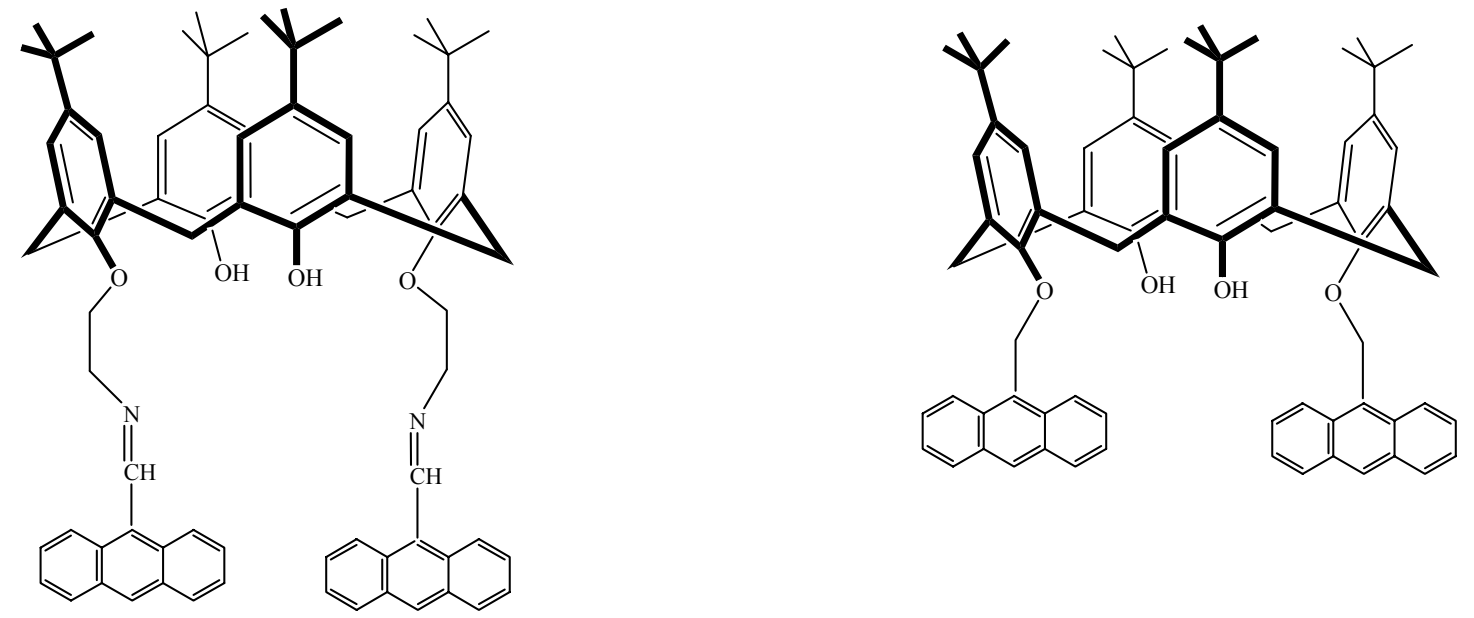


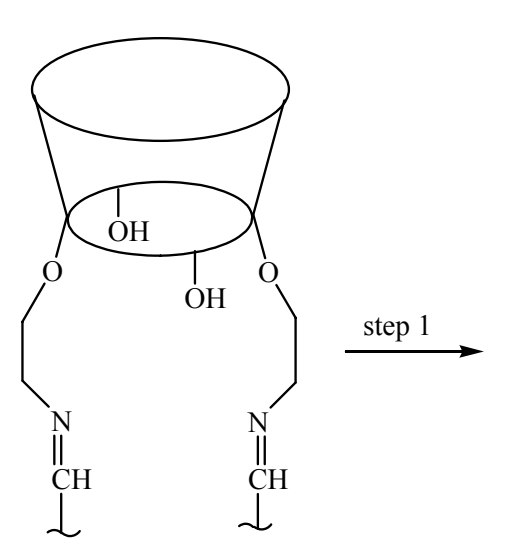

5

$\mathrm{M}^{2+}=\mathrm{Cu}^{2+}, \mathrm{Zn}^{2+}$

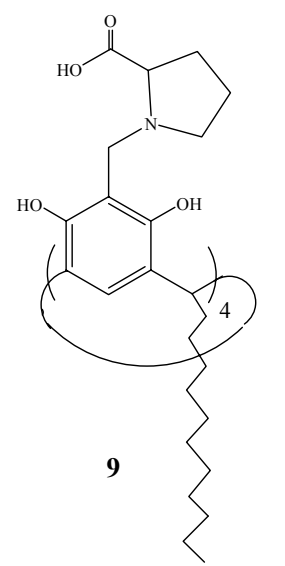

\section{Scheme 1}

The complexation of calixazacrowns $10 a-c$ and their homologues $11 \mathbf{a}, \mathbf{b}$ with $\mathrm{Cu}^{2+}$ was studied. It was found that $\mathrm{Cu}^{2+}$ forms with $\mathbf{1 0 a}$ the $1: 1$ complex i.e. $\mathbf{C u}^{2+} \cdot \mathbf{1 0 a}$, and with $\mathbf{1 1 a}$ the 2:1 complex, i.e. $\left(\mathrm{Cu}^{2+}\right)_{2} \cdot \mathbf{1 1 a}$; compounds 10a and 11a are promising for the design of fluorescent chemosensors for $\mathrm{Cu}^{2+}$ ion. ${ }^{44}$ It should be mentioned that 10a may form in the solid state channels for small molecules, e.g. methanol.

Chiral calix[5] arenes $(\boldsymbol{R})-\mathbf{1 2}$ and $(\boldsymbol{S})-\mathbf{1 2}$ have been synthesized. It was observed that they selectively bind $\mathrm{Cu}^{2+}$ over other $\left(\mathrm{Li}^{+}, \mathrm{Na}^{+}, \mathrm{K}^{+}, \mathrm{Mg}^{2+}, \mathrm{Ba}^{2+}, \mathrm{Mn}^{2+}, \mathrm{Co}^{2+}, \mathrm{Ni}^{2+}\right.$ and $\left.\mathrm{Zn}^{2+}\right)$ ions. ${ }^{55}$

The complexes $\left[\mathbf{C u}^{2+} \cdot(\boldsymbol{R})-\mathbf{1 2}\right]$ and $\left[\mathbf{C u}^{2+} \cdot(\mathbf{S})-\mathbf{1 2}\right]$ may be used as binary hosts to recognize carbohydrates. The fluorescent titration results have shown that they selectively recognize D$(+)$ gluconic acid $\delta$-lactone over other carbohydrates, such as D- $(+) x y l o s e$, D-(-)ribose, 2-deoxy-D-ribose, D-(-)arabinose and D-(+)glucose.

Calix[6]arenes 13 and 14 react with bis(bromomethyl)-1,10-phenanthroline to give bridged calix[6]arenes 15 and 16, respectively. ${ }^{56-58}$ Compound $\mathbf{1 6}$ is chiral. It should be noted that in the 
crystal of $\mathbf{1 6}$ the arene rings adopt an $u d i u d i(u=u p ; d=d o w n ; i=i n)$ conformation, although in the starting 14 all-up conformation predominates. This observation indicates that during the bridging process leading from $\mathbf{1 4}$ to 16, two arene rings invert from an up to a down orientation. Reaction of $\mathbf{1 5}$ with chiral reagents, e.g. camphor sulfonyl chloride $\mathbf{1 7}$ affords chiral calix[6]arene derivative $\mathbf{1 8 .}$

The presence of the phenanthroline bridge in 15, 16 and 18 enables the chelation of $\mathrm{Cu}^{+}$ ions; the formed complexes were tested as ligands for copper ion in the $\mathrm{Cu}(\mathrm{I})$ catalyzed cyclopropanation of styrene and indene with ethyl diazoacetate 19. ${ }^{59}$ It was found that chiral 16 and 18 alter the stereoselectivities of the cyclopropanations of styrene towards cis and indene towards endo products, i.e. in the same direction as in the case of nonmodified 15.

In biological systems the coordination properties of the metal ion are controlled by proteins. In order to mimic such biological coordination, ligands basing on calix[6]arenes functionalized at the narrow rim by nitrogen arms were designed. In these ligands the aza-donors secure the first coordination sphere with one open binding site directed toward the center of calixarene cavity. The calixarene narrow rim defines the second coordination sphere, whereas the aromatic units of the calixarene act as a hydrophobic funnel selecting and driving the guest molecule to the metal center. $^{60}$

The complexation of $\mathrm{Cu}^{+}$and $\mathrm{Cu}^{2+}$ ions by tris(pyridine)calix[6]arene $\mathbf{2 0}$ has been studied. ${ }^{61,62}$ It was observed that $\mathbf{C u}^{+} \cdot \mathbf{2 0}$ upon addition of $\mathrm{MeCN}$ affords complex $\mathbf{C u}^{+} \cdot \mathbf{2 0} \cdot \mathbf{M e C N}$ in which $\mathrm{Cu}^{+}$ion has the tetrahedral $\left(\mathrm{T}_{\mathrm{d}}\right)$ geometry and is coordinated by three pyridine nitrogen atoms and by nitrogen atom of $\mathrm{MeCN}$ ligand situated inside the cavity.

However, in $\mathbf{C u}^{2+} \cdot \mathbf{2 0} \cdot \mathbf{M e C N}$, the $\mathrm{Cu}^{2+}$ ion has the square-based pyramidal geometry (SBP); in the complex one nitrogen arm is in the apical site, and the water molecule is situated outside the cavity.

In both complexes, i.e. $\mathbf{C u}^{+} \cdot \mathbf{2 0} \cdot \mathbf{M e C N}$ and $\mathbf{C u}^{2+} \cdot \mathbf{2 0} \cdot \mathbf{M e C N}$, as well as in the transition state A the $\mathrm{CH}-\pi$ interactions between the phenyl units of the cavity and the methyl group of $\mathrm{MeCN}$ exist. The $\mathrm{MeCN}$ unit plays in these complexes an important role since it controls the coordination of $\mathrm{Cu}^{+}$and $\mathrm{Cu}^{2+}$ ions by combination of the $\mathrm{Cu} / \mathrm{N}$ (nitrile) bond and second sphere interactions; the presence of $\mathrm{MeCN}$ is necessary to maintain the architecture of complexes. The existing host-guest interaction generates a supramolecular stress resulting in a driving force pulling the $\mathrm{Cu}^{+}$or $\mathrm{Cu}^{2+}$ ions inside the calixarene cavity. The above $\mathrm{Cu}^{+} / \mathrm{Cu}^{2+}$ systems are of interest in the study of biomimetic processes of proteins.

It was established that calix[6]arene capped at the narrow rim by a tmpa unit (where tmpa $=$ [tris(2-methylpyridyl)amine]), i.e. 21 upon treatment with $\mathrm{Cu}^{2+}$ ions and the guest $\mathrm{G}$ affords funnel complexes. ${ }^{63,64}$

The reaction of 21 with $\mathrm{Cu}\left(\mathrm{ClO}_{4}\right)_{2}\left(\mathrm{H}_{2} \mathrm{O}\right)_{6}$ and guests $\mathrm{G}(\mathrm{G}=\mathrm{MeCN}, \mathrm{DMF})$ yields the $\mathrm{Cu}^{2+}$ complexes $\left.\left[\mathbf{C u}^{2+} \cdot \mathbf{2 1} \cdot \mathbf{G}\right)\right]^{2+}$ i.e. $\mathbf{2 2}$; when instead of $\mathrm{G}$ the anion $\mathrm{X}^{-}\left(\mathrm{X}^{-}=\mathrm{OH}^{-}, \mathrm{Cl}^{-}, \mathrm{F}^{-}, \mathrm{N}_{3}^{-}\right)$is used, the $\mathrm{Cu}^{+}$complexes $\left[\mathbf{C u}^{+} \cdot \mathbf{2 1} \cdot \mathbf{X}\right]^{+}$, i.e. $\mathbf{2 3}$ are formed. Complexes $\mathbf{2 3}$ may also be obtained by reacting 22 with anions $\mathrm{X}^{-}$. The $\mathrm{Cu}^{2+}$ complexes $\mathbf{2 2}$ are very stable; the 5-coordinate $\mathrm{Cu}^{2+}$ ion is strongly bound to the tmpa cap in a trigonal bipyramidal (TBP) 
geometry; they show high affinity for neutral guests that sterically fit into the calix cavity. These properties are similar to those of funnel $\mathrm{Cu}^{2+}$ complexes based on calix[6]tris(imidazole) 24 and on calix[6]tren 25 (where tren $=$ tris $(2$-aminoethyl)amine).

An important difference however exists, resulting from the fact that the second coordination sphere provided by a narrow rim in $\mathbf{2 2}$ forms a different electronic environment than in the case of 24 and 25. In 24 and 25 the oxygen atoms connecting phenyl moieties with imidazole units (in 24) or with nitrogen atoms (in 25) are directed inwards. In the case of complexes 22, however, the structure is rigid due to the presence of tmpa, therefore the oxygen atoms connecting phenyl moieties with pyridyl units are directed outwards, i.e. towards the bulk.

In this way the dipolar inversion of the second coordination sphere responsible for anion binding occurs. As a result, the $\mathrm{Cu}^{2+}$ ion in $\mathbf{2 2}$ is able to bind a large variety of anions, while in the case of 24 and $25^{65-68}$ the anion binding in the cavity is strongly disfavored because of charge-dipole repulsion at the narrow rim. The above complexes are highly biologically relevant to mononuclear active sites of metalloenzymes. ${ }^{63}$

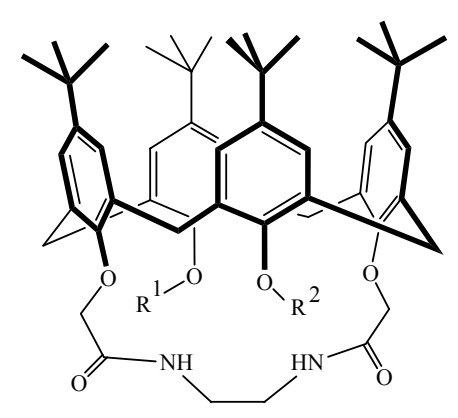

10

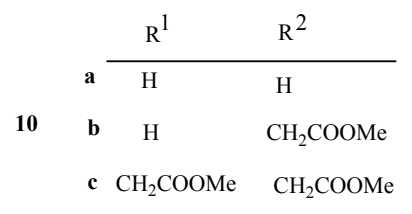

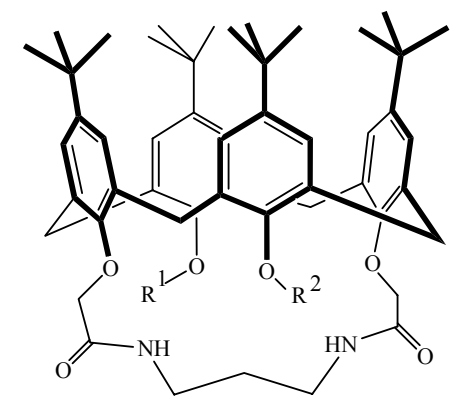

11

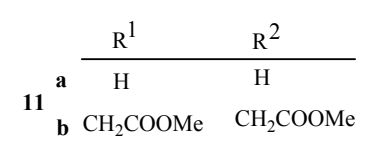

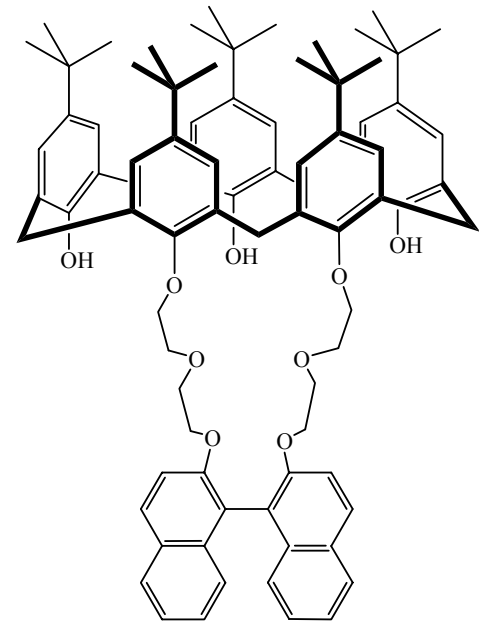

12 

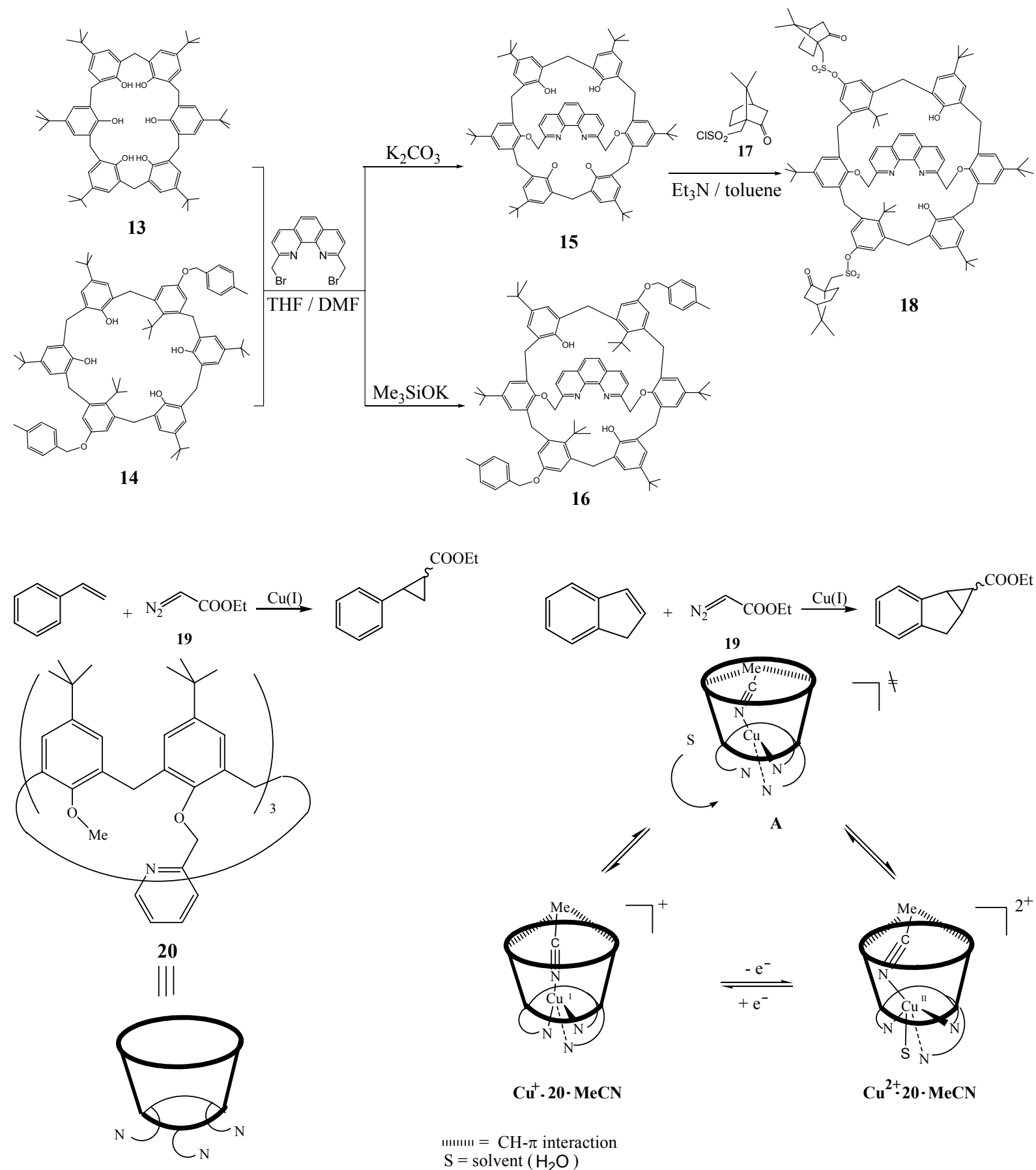

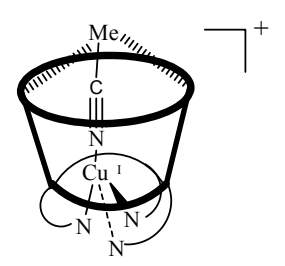

$\mathrm{Cu}^{+} \cdot \mathbf{2 0} \cdot \mathrm{MeCN}$

III!!! $=\mathrm{CH}-\pi$ interaction $\mathrm{S}=$ solvent $\left(\mathrm{H}_{2} \mathrm{O}\right)$ 


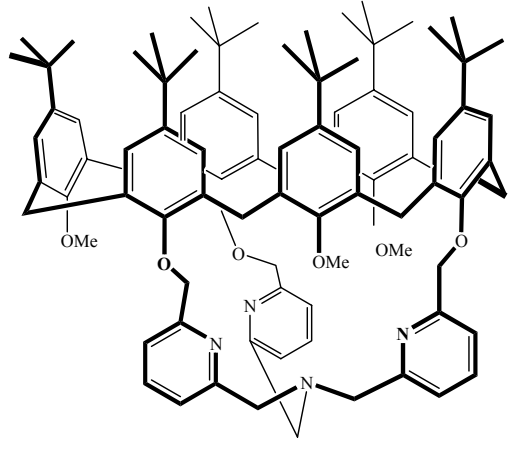

21

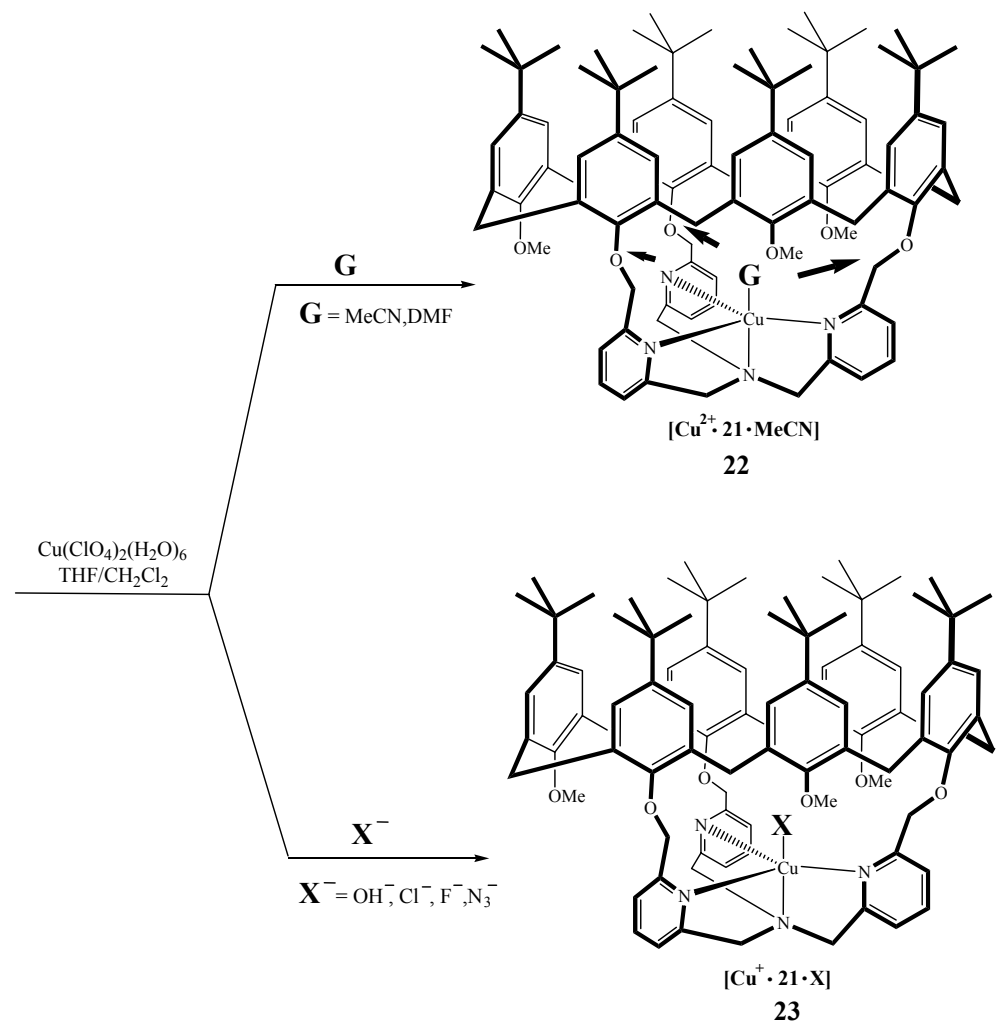

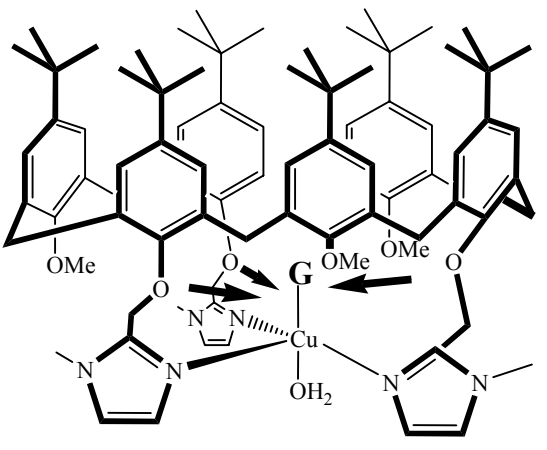

24

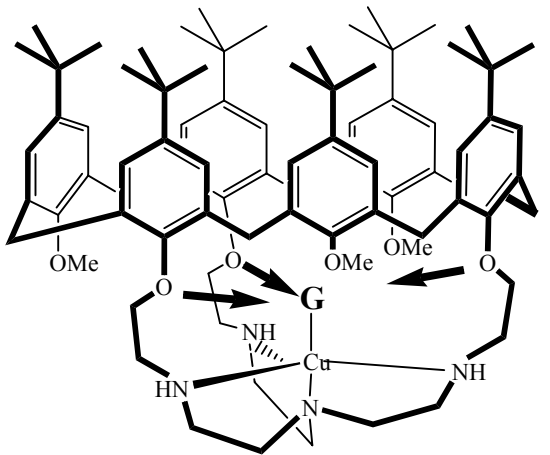

25

Scheme 2

\section{Calixarene complexes with silver ions}

In the study of calixarene complexes with silver ions ${ }^{69-73}$ it was found that calixarenes $\mathbf{2 6}$ and 27 containing sulfur atoms as soft binding site may be used as cation sensors for ion-selective electrodes. In order to investigate the influence of neighboring halogen atoms on cation selectivity, the fluorosubstituted (i.e. 28, 29) and dichlorosubstituted (i.e. 30-32) analogues of 26, 27 were studied. $^{74}$ The ion-selective electrodes based on 26-32 as neutral ionophores have 
been prepared, and their selectivity coefficients for $\mathrm{Ag}^{+}$were examined against alkali metal, alkaline earth metal, lead, and some transition metal ions using the fixed interference method (FIM). It was found that they have high $\mathrm{Ag}^{+}$selectivity over $\mathrm{Na}^{+}, \mathrm{K}^{+}, \mathrm{NH}_{4}^{+}, \mathrm{Ca}^{2+}, \mathrm{Cu}^{2+}, \mathrm{Zn}^{2+}$ and $\mathrm{Cd}^{2+}$ interfering ions, except for $\mathrm{Hg}^{2+}$.

Calixarenes 28-32 contain sulfur atoms as a soft binding site and neighboring halogen atoms as assistant donors taking part in complexation of silver ions. The ${ }^{1} \mathrm{H}$ NMR analysis has shown that 29 exists as several conformers in solution, and the ${ }^{19} \mathrm{~F}$ NMR spectra of $\mathbf{A g}^{+} \cdot \mathbf{2 9}$ revealed that the fluorine atoms participate in complexation of silver ion.

Calixarenes 33-36 bearing allyl groups and calixarenes 37a,b containing benzothiazole units have been investigated in view of their affinity towards $\mathrm{Ag}^{+}$ion; among them 34, 37a and 37b were used for construction of $\mathrm{Ag}^{+}$ion-selective electrodes. ${ }^{75,76}$ It was observed that $\mathbf{3 7 b}$ coordinates $\mathrm{Ag}^{+}$more strongly than $37 \mathbf{a}$.

It was observed that calixarenes 38a-c form 1:1 inclusion complexes with $\mathrm{Ag}^{+}$; their stability constants, determined by the ESI-MS (electrospray-ionization mass spectrometry) method decrease in the order $\mathbf{3 8 b}>\mathbf{3 8} \mathbf{a}>\mathbf{3 8} \mathbf{c}$. $^{72}$

The complexation of calixarene 39 with $\mathrm{Ag}^{+}$was investigated. ${ }^{77-79}$ Although calixarene 39 has low solubility, the amines can solubilize it via acid-base host-guest chemistry, resulting in the abstraction of a single proton from 39 by the amine. Majority of inclusion complexes of 39 are formed in solution by van der Waals interactions of a guest with hydrophobic cavity of $\mathbf{3 9}$, leading to $1: 1$ or $2: 1$ host-guest systems. ${ }^{80}$ In the solid state, however, the symmetry of the calixarene is disrupted, therefore simple 1:1 or 2:1 host-guest complexes are not formed.

It was observed that the solution of $\mathbf{3 9}$ and $\mathrm{AgNO}_{3}$ in ethylenediamine $\mathbf{4 0}$ after evaporation of excess solvent affords crystals of the clathrate $\left[\mathbf{A g}^{+} \cdot \mathbf{3 9} \cdot(\mathbf{4 0})_{3}\right]$, i.e. 41 . In 41 one molecule of 39 interacts with three ethylenediamine 40 molecules coordinating one $\mathrm{Ag}^{+}$ion. The calixarene 39 serves as a counterion, a single proton being abstracted from one of its phenol groups by the excess ethylenediamine left behind as solvent. In $\mathbf{4 1}$ one bidentate-chelating molecule of $\mathbf{4 0}$ is situated within the calixarene (endo), whereas two singly coordinated molecules of $\mathbf{4 0}$ reside outside the calixarene cavity (exo); the four-coordinate $\mathrm{Ag}^{+}$ion has a distorted tetrahedral geometry. $^{77}$

The clathrate $\mathbf{4 1}$ is further stabilized through a network of hydrogen bonds. The endo coordinated amine units interact with the phenolic hydroxyl groups of calixarene 39. The free amino groups of the two exo molecules of $\mathbf{4 0}$ form weak hydrogen bonds with free amino groups of the adjacent molecules of 41. Due to the above hydrogen bonds, the distortion of the capped structural motif takes place.

It was observed that upon deamination occurring by heating the sample 41, its color changes from white to yellow and then to brown, indicating the reduction of the $\mathrm{Ag}^{+}$ion and formation of nanocrystalline clusters consisting of $\mathbf{3 9}$ and metallic silver.

The oligophenylene-substituted calix[4]crowns 42a-d form complexes with $\mathrm{Ag}^{+}$ion. ${ }^{81}$ The binding of crown ether moiety with $\mathrm{Ag}^{+}$ion is weak, therefore the reversible disassembling of 
the complex in the presence of KI is possible. It should be pointed out that despite weakness, this interaction is useful in the design of supramolecular structures.
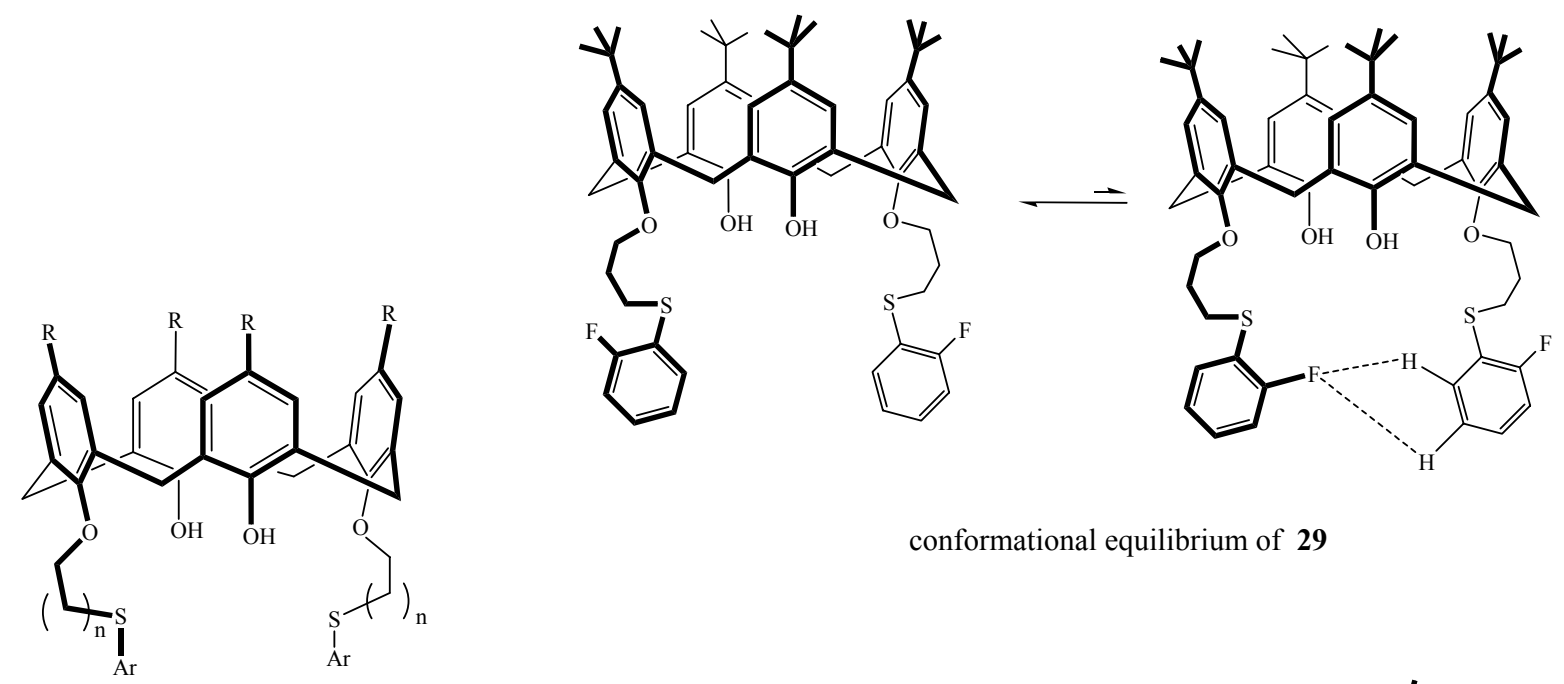

conformational equilibrium of $\mathbf{2 9}$
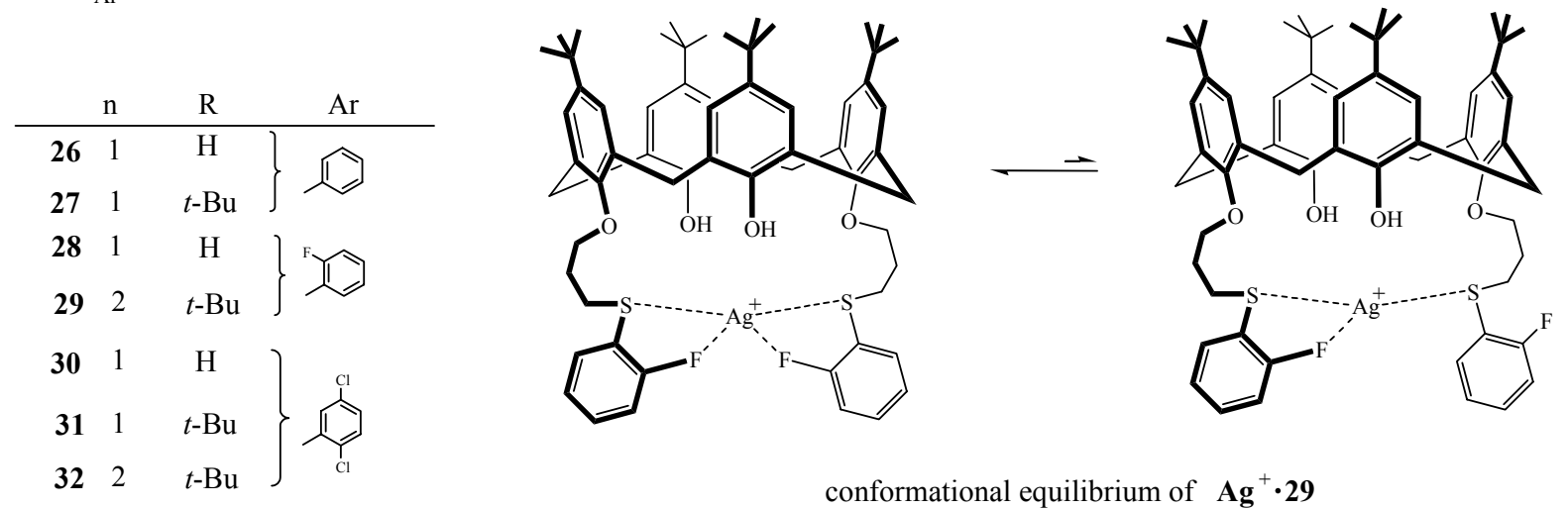

conformational equilibrium of $\mathbf{A g}^{+} \cdot \mathbf{2 9}$
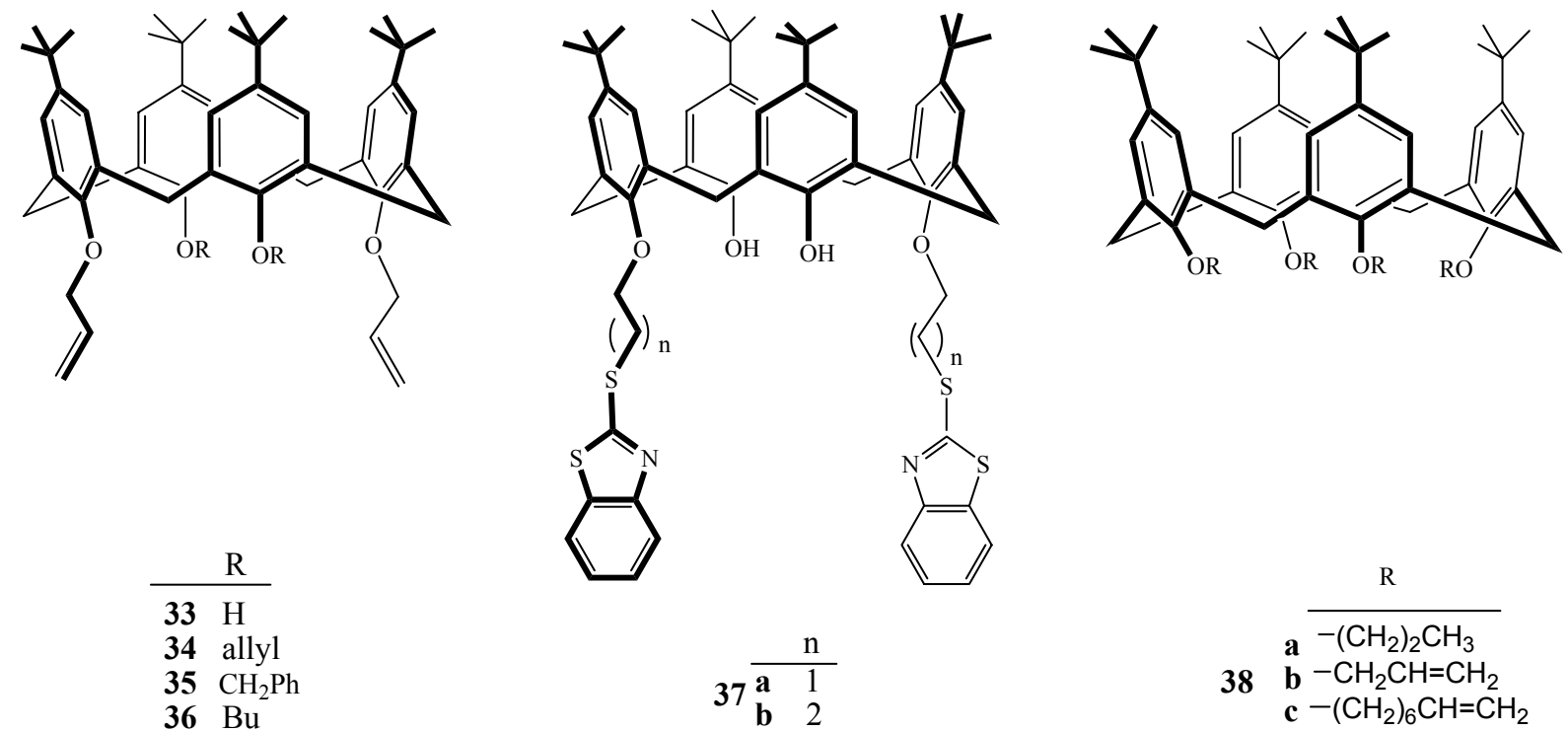

$37 \begin{array}{ll}\mathbf{a} & 1 \\ \mathbf{b} & 2\end{array}$

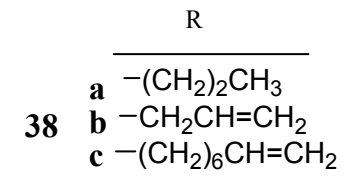




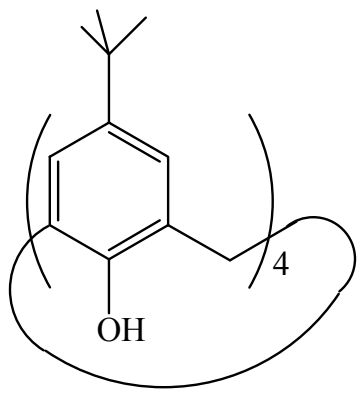

39

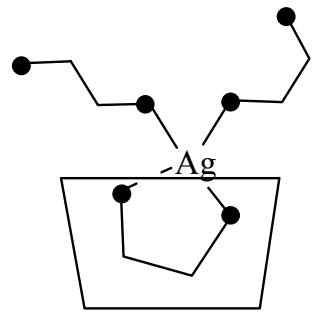

- = ethylenediamine $\mathbf{4 0}$

[Ag• 39・ (40) ]

41

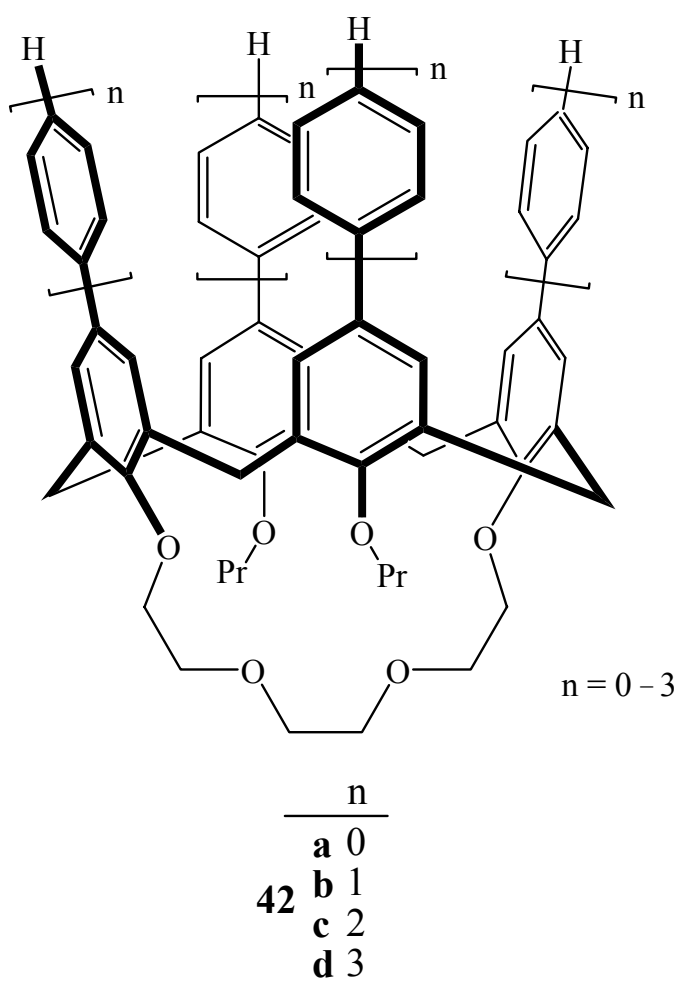

Scheme 3

\section{Calixarene complexes with gold ions}

In the study of calixarene gold complexes ${ }^{49,82}$ it was observed that the compound $\mathbf{4 3}$ containing four two-coordinate linear gold halide units exists as an equilibrium between two boat conformers $43 \mathrm{a}$ and $\mathbf{4 3 b}$ which undergo an easy conformational exchange ${ }^{83-85}$ in solution. In order to synthesize resorcinarene digold complexes the disilver complexes 44a-c were treated with $\left[\mathrm{AuCl}\left(\mathrm{SMe}_{2}\right)\right]$. The reactions occur with the precipitation of silver chloride, and as products the resorcinarene digold complexes $45 \mathbf{a}-\mathbf{c}$ are formed. ${ }^{83}$

It was found that the reaction of resorcinarene 46 with $\left[\mathrm{AuCl}\left(\mathrm{SMe}_{2}\right)\right]$ yields polymeric complex $\left[\mathbf{4 6}_{4}\{\mathrm{AuCl}\}_{2} \cdot\left[\mathbf{4 6}_{4} \mathrm{Au}_{2}\right]\left[\mathrm{AuCl}_{2}\right]_{2}\right.$, i.e. 47, consisting of two different species: the dicationic component $\mathbf{A}$ and the neutral component $\mathbf{B}$. In the dicationic component $\mathbf{A}$ the gold(I) centers have linear S-Au-S coordination, with chelation of each gold(I) center by two sulfur atoms of the thiophosphinate groups. The anions of 47 are $\left[\mathrm{AuCl}_{2}\right]^{-}$.Thus the dicationic component is analogous to the dications in disilver and digold (I) complexes 44 and $\mathbf{4 5}$. The neutral component $\mathbf{B}$ has two linear S-Au-Cl units, one at each end of the molecule of 47; two sulfur atoms are noncoordinated. In both components the resorcinarene molecule has a boat 
conformation in which the thiophosphinate-derivatized arene rings are in the flattened position, and the acylated rings stand upright. ${ }^{83}$

It should be pointed out that the complex $\mathbf{4 7}$ has an unusual polymeric structure in the solid state in which molecules $\mathbf{A}$ and $\mathbf{B}$ are linked via $\mathrm{Au} \cdots \mathrm{Au}$ interactions at each end; in this way two intermolecular aurophilic bonds are formed. The presence of these aurophilic attractions between the chelated S-Au-S gold centers and the linear $\mathrm{S}-\mathrm{Au}-\mathrm{Cl}$ gold centers results in an infinite, alternating pattern of the two different components $\mathbf{A}$ and $\mathbf{B}$, which create this polymeric structure. The solid-state structure of the complex $\mathbf{4 7}$ contains both the chelate form in $\mathbf{A}$ and the terminal ligand form in $\mathbf{B}$.

The reaction of calixarene $\mathbf{4 8}$ with four equivalents of [AuCl(THT)] (where THT = tetrahydrothiophene)] affords the tetragold complex 49. ${ }^{86}$ In the study of stepwise titration of 48 with $\mathrm{AuCl}$ (THT) it has been shown that the first complexation step affords a mononuclear species 50, existing in equilibrium with the assembly 51. The NMR study indicates the dynamic behavior of 50; its all four phosphorus atoms are involved in coordination. The chloro-gold units jump from one phosphorus atom to another; it should be pointed out that both intermolecular and intramolecular jumps are possible. Molecular mechanics calculations have shown the tetrahedral geometry of gold centers.

The binding of the second gold unit is more difficult than in the case of the first one. The addition of the second $\mathrm{AuCl}(\mathrm{THT})$ molecule leads to the dinuclear gold complex $\mathbf{5 2}$ existing in an equilibrium with the assembly $\mathbf{5 3}$. The X-ray structure of $\mathbf{5 3}$ shows that the linking gold atoms having near-trigonal geometry. The addition of the third AuCl(THT) molecule results in formation of labile complex 54, which upon reaction with the fourth $\mathrm{AuCl}(\mathrm{THT})$ molecule yields 49.

In the investigation of vacuum deposition of metal-containing organic compounds ${ }^{87-89}$ it was observed that the incorporation of coordinated metal atoms has a stabilizing effect. ${ }^{90-92}$ The scanning tunneling microscopy (STM) results indicate that the stability of a large organic compound sublimated onto a $\mathrm{Au}$ (111) surface under ultrahigh vacuum conditions may be considerably enhanced by coordinating it to gold atoms prior to deposition. For this purpose gold-functionalized calix[4]arene $\mathbf{5 5}$ containing two arms derived from melamine units and terminating by triphenylphosphine groups has been synthesized. 


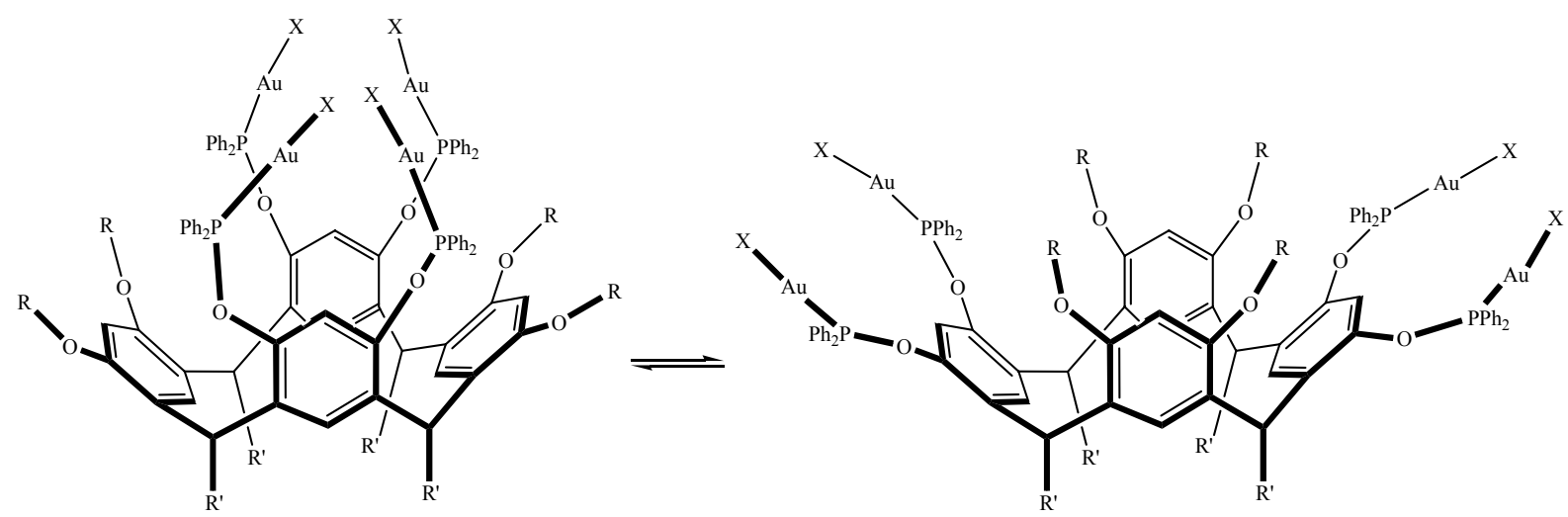

$$
\begin{aligned}
& \mathrm{R}=\text { alkyl } \\
& \mathrm{R}^{\prime}=\mathrm{CH}_{2} \mathrm{CH}_{2} \mathrm{Ph} \\
& \mathrm{X}=\text { halide }
\end{aligned}
$$

43b

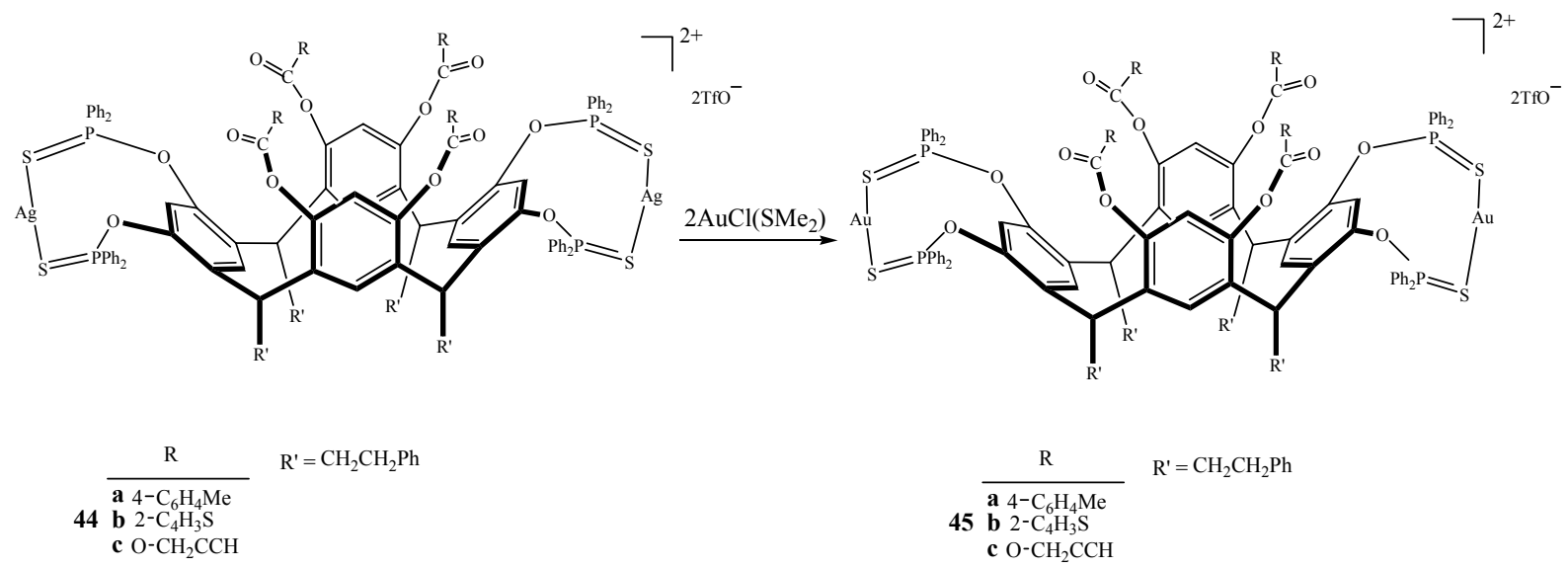




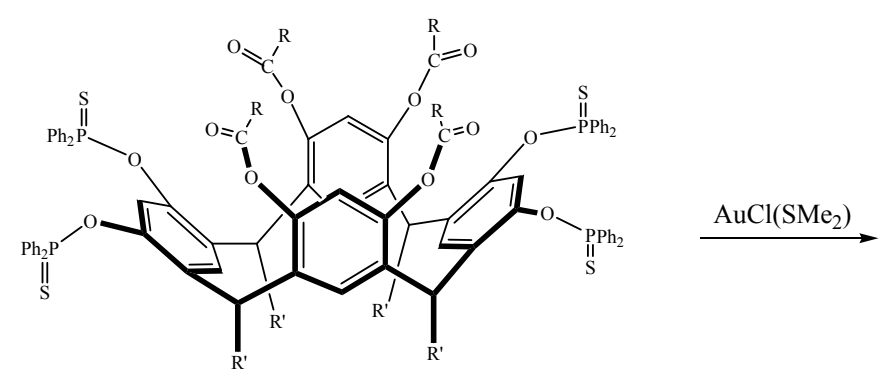

$$
\begin{aligned}
& \mathrm{R}=4-\mathrm{C}_{6} \mathrm{H}_{4} \mathrm{Me} \\
& \mathrm{R}^{\prime}=\mathrm{CH}_{2} \mathrm{CH}_{2} \mathrm{Ph}
\end{aligned}
$$

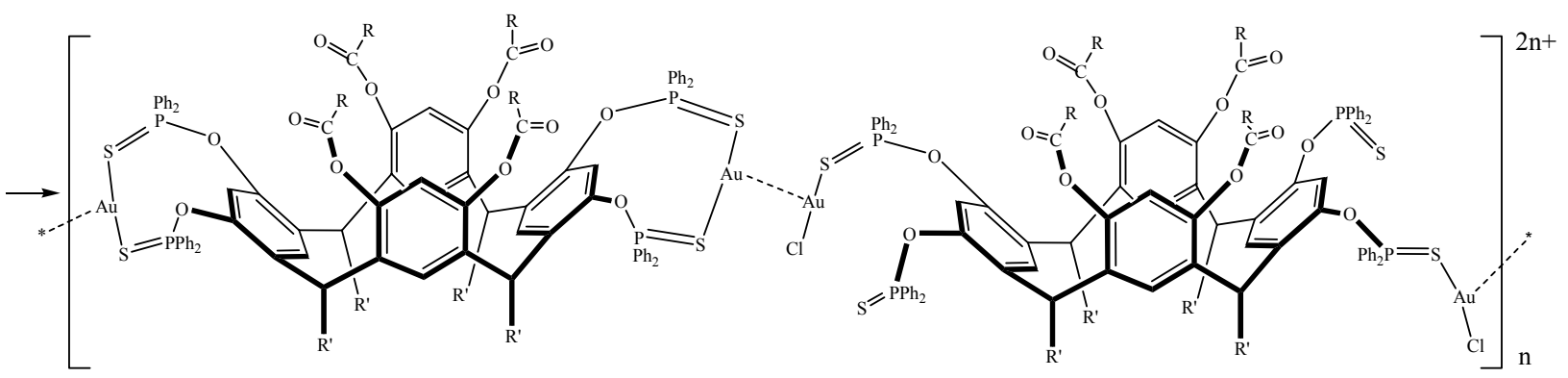

dicationic component

A

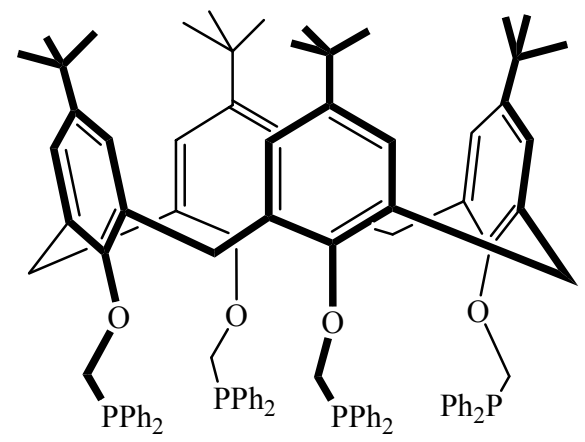

48
47
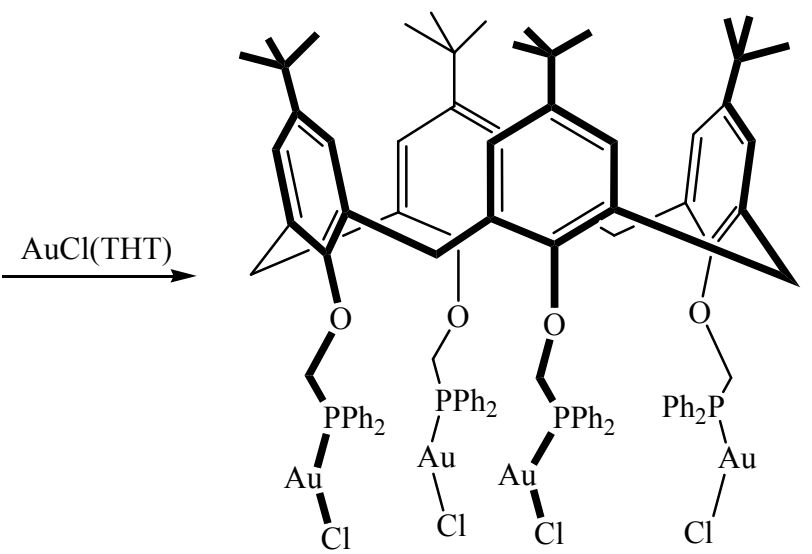

49

THT $=$ tetrahydrothiophene 

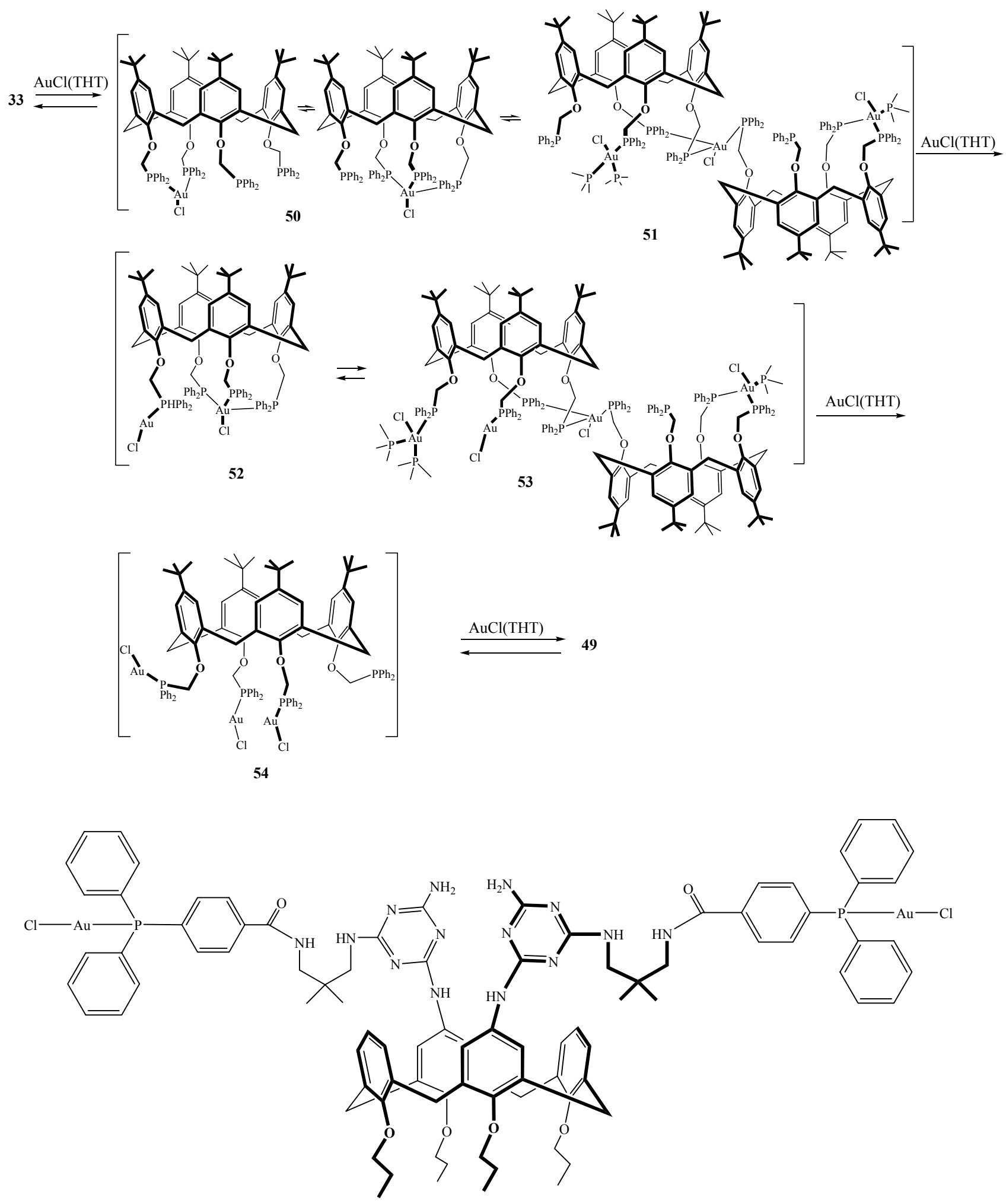

55

Scheme 4 


\section{Calixarene complexes with zinc ions}

Zinc is widely used in fine chemicals and paint industries, as well as in electroplating; zinc is also present in high protein foods. Excess of $\mathrm{Zn}^{2+}$ ions is toxic for humans, therefore methods for zinc monitoring are of importance. ${ }^{93}$ Calixarene zinc complexes are intensively studied; ${ }^{49,78,94-96}$ some examples will be shown below.

Investigations of complexing properties of calix[4]arene $\mathbf{5 6}$ towards cations and anions have shown that different moieties of the pendant arms serve as active sites for complexation, therefore $\mathbf{5 6}$ may be considered as a ditopic receptor. Calixarene $\mathbf{5 6}$ forms with $\mathrm{Zn}^{2+}$ ion the complex $\mathbf{Z n}^{2+} \cdot \mathbf{5 6}$; in this process the hydroxyl and carbonyl groups of the pendant arms at the narrow rim of $\mathbf{5 6}$ function as active sites for interaction..$^{97,98}$

It was established that 4-t-butylcalix[4]arene 39 may be used as a $\mathrm{Zn}$ (II) selective potentiometric sensor. ${ }^{93}$ Poly(vinyl chloride) based membranes containing 39 show a very good selectivity for $\mathrm{Zn}^{2+}$ over other mono-, bi- and trivalent cations; one should point out their fast response and good reproducibility. The sensor may be used as an indicator ionoselective electrode in the potentiometric titration of $\mathrm{Zn}^{2+}$ against EDTA ${ }^{27,28}$ (EDTA = ethylenediaminetetraacetic acid) and for estimation of zinc ions in industrial waste waters.

It is known that macrocyclic host molecules are promising models for enzymes. When transition metals are coordinated in proximity to the hydrophobic cavities of receptors, the macrocycles function as metalloenzymes. ${ }^{99}$ Metalloenzyme models acting in aqueous solution have been designed by employing self-assembly of the $p$-sulfonatocalix[4]arene 57 (used as a macrocyclic host able to bind cationic guests), bicyclic azoalkanes 58-60 ${ }^{100,101}$ serving as guests, and $\mathrm{Zn}^{2+}$ as a metal ion. ${ }^{102}$ In this model the metal-guest bond formation is host-assisted, i.e. is templated by the host. In the soformed ternary complex consisting of $\mathbf{5 7}$, the guest and the metal ion, the guest is held by hydrophobic interactions with the host, while the metal ion is held by Coulombic attraction of negative charges situated at the wide rim of 57. If the guest is a weak ligand, the host can assist, i.e. can template the formation of a metal-guest bond. The guest used should be large enough to maximize hydrophobic interactions, and sufficienty small to enable the docking of cations to the wide rim of calixarene 57. The guest should contain functional groups to allow metal-guest interactions.

Bicyclic azoalkanes 58-60 have been chosen as guests. Among them, $\mathbf{5 8}$ is the most convenient guest, since its binding constant with $\mathbf{5 7}$ is the highest, and its small and spherical shape enables the binding of metal ions. ${ }^{103}$ The formation of the complex $\mathbf{5 7 \cdot 5 8}$ and the subsequent binding of metal ion may be controlled by optical spectroscopy, since $\mathbf{5 8}$ shows strong fluorescence in water, as well as the near UV absorption.

When $\mathbf{5 7}$ is added to an aqueous solution of $\mathbf{5 8}$, the 1: 1 complex is formed. The subsequent addition of $\mathrm{Zn}^{2+}$ results in the formation of a ternary complex $\mathbf{Z n}^{2+} \cdot \mathbf{5 7 \cdot 5 8}$, in which the azo group of $\mathbf{5 8}$ serves as a monodentate ligand. This behavior, i.e. that the host brings $\mathbf{5 8}$ and $\mathrm{Zn}^{2+}$ together is similar to the function of enzyme bringing together the substrate and the catalytic center. The formation of the ternary complex $\mathbf{Z n}^{2+} \cdot \mathbf{5 7 \cdot 5 8}$ is an example of a cooperative 
binding. ${ }^{102}$ It is known that $\mathbf{5 8}$ shows in water a high fluorescence, which is quenched upon complexation with 57. When $\mathrm{Zn}^{2+}$ ions (which do not quench the fluorescence of free 58) are added, the fluorescence of $\mathbf{5 8}$ is further decreased, indicating the formation of the ternary complex.

It should be noted that $\mathbf{5 9}$ and $\mathbf{6 0}$ do not form similar ternary complexes, in the case of $\mathbf{5 9}$ due to steric hindrance and in the case of $\mathbf{6 0}$ due to charge repulsion between $\mathrm{Zn}^{2+}$ cations and the positive ammonium group of $\mathbf{6 0}$. In these both cases of 59 and 60 the release of the guest occurs, due to the competitive binding of $\mathbf{5 9}$ or $\mathbf{6 0}$ and $\mathrm{Zn}$ with $57 .{ }^{102}$ These observations indicate the high selectivity of 57, since it forms ternary complex only with $\mathbf{5 8}$ and not with $\mathbf{5 9}$ or $\mathbf{6 0}$, although the structural differences of $\mathbf{5 9}$ and $\mathbf{6 0}$ as compared to $\mathbf{5 8}$ are slight.

The above results show possibility of two modes of binding, i.e. cooperative and competitive binding. The cooperative binding occurs when steric and electrostatic factors are favorable and when the geometry allows the formation of the metal-guest bond. The binding constant of $\mathbf{5 7 \cdot 5 8}$ increases fourfold by addition of $\mathrm{Zn}^{2+}$; this observation indicates a positive cooperativity of the binding, i.e. the synergistic effect. This increase of binding constant of $\mathbf{5 7 . 5 8}$ in the presence of metal ion, resulting from metal-guest interaction is promising in sensor design.

UV spectral analysis has revealed that at pH 2 the guest $\mathbf{5 8}$ in $\mathbf{5 7}$ is protonated to give the complex $\mathbf{5 8} \cdot \mathbf{5 7} \cdot \mathbf{H}^{+}$. Upon addition of $\mathrm{Zn}^{2+}$ ions, the complex $\mathbf{Z n}^{\mathbf{2 +}} \cdot \mathbf{5 7 \cdot 5 8}$ is formed. That means that in this particular case, $\mathrm{Zn}^{2+}$ ions do not destabilize the complex of $\mathbf{5 6}$ with a cationic guest, i.e. the release of $\mathbf{5 8}$ does not occur as it took place in the case of $\mathbf{6 0}$, but the guest is deprotonated by $\mathrm{Zn}^{2+}$ which forms the metal-guest bond. This behavior resembles function of $\mathrm{Zn}^{2+}$ ions in hydrolytic metalloenzymes, where $\mathrm{Zn}^{2+}$ ions deprotonate ligands by formation of metal-ligand bonds. ${ }^{102,104}$

Calix[6]arenes may be used as hydrophobic hosts, their large cavity enables inclusion of a variety of organic guests. Since calix[6]arenes are very flexible, in order to obtain a cavity able to include a guest they must be restricted in a cone conformation. ${ }^{68}$

In order to design biomimetic receptors, the system $\mathbf{6 1}$ mimicking metalloenzyme active sites by binding metal center incorporated inside a calix[6]arene cavity with a neutral guest has been developed. This system is based on calix[6]arene bearing three imidazole arms and contains the $\mathrm{Zn}^{2+}$ ion. ${ }^{105}$ The imidazole arms are mimicking the histidine residues of the protein. The $\mathrm{Zn}^{2+}$ ion is coordinated in a tetrahedral geometry. Such funnel complex, increasing Lewis acid character of metal ion in the hydrophobic neutral environment is highly sensitive to different guests $(\mathrm{G})$ of an electron donor character, e.g. $\mathrm{RNH}_{2}, \mathrm{ROH}, \mathrm{RCONH}_{2}, \mathrm{RCN}, \mathrm{RCOOH}$; their encapsulation leads to 61. The hydrophobic pocket is a selective molecular funnel for neutral species. This system $\mathbf{6 1}$ is similar to $\mathbf{2 4}$, i.e. to copper funnel complex based on calix[6]arene bearing three imidazole arms and $\mathrm{Cu}^{2+}$ ion, containing the guest molecule $\mathrm{G}$.

In the study of biomimetic zinc funnel complexes basing on calix[6]arene, it was observed that calix[6]arenes $62 \mathbf{a} \cdot \mathbf{H}$ and $\mathbf{6 2 b} \cdot \mathbf{H}$ bearing two imidazole arms and one phenol arm may form three types of complexes with $\mathrm{Zn}^{2+}$ ion, namely dicationic, monocationic and neutral ones. ${ }^{106}$ 
(1) It was found that $\mathbf{6 2 a} \cdot \mathbf{H}$ reacts with $\mathrm{Zn}\left(\mathrm{H}_{2} \mathrm{O}\right)_{6}\left(\mathrm{ClO}_{4}\right)_{2}$ in THF to give the dicationic complex $\left[\mathrm{Zn}(\mathbf{6 2} \mathbf{a} \cdot \mathbf{H})\left(\mathrm{H}_{2} \mathrm{O}\right)\right]\left(\mathrm{ClO}_{4}\right)_{2}$, i.e. $\mathbf{A}$ in which $\mathrm{Zn}^{2+}$ is coordinated to three nitrogen atoms, to the linking $\mathrm{OH}$ group and to $\mathrm{H}_{2} \mathrm{O}$ molecule. One should mention that in the case of $\mathbf{6 2} \mathbf{b} \cdot \mathbf{H}$ the formation of a dicationic complex similar to $\mathbf{A}$ was not observed. When the $\mathrm{CDCl}_{3}$ solution of $\mathbf{A}$ was treated with a small neutral guest $\mathrm{G}$, e.g., $\mathrm{ROH}, \mathrm{RCN}, \mathrm{RCONH}_{2}$ (ethanol, acetonitrile, propionitrile, acetamide), the exchange of $\mathrm{H}_{2} \mathrm{O}$ for $\mathrm{G}$ molecule took place, affording the dicationic complex $[\mathrm{Zn}(\mathbf{6 2} \mathbf{a} \cdot \mathbf{H})(\mathrm{G})]\left(\mathrm{ClO}_{4}\right)_{2}$.

(2) The reaction of $\mathbf{6 2} \mathbf{a} \cdot \mathbf{H}$ and $\mathbf{6 2} \mathbf{b} \cdot \mathbf{H}$ with $\mathrm{Zn}\left(\mathrm{H}_{2} \mathrm{O}\right)_{6}\left(\mathrm{ClO}_{4}\right)_{2}$ in $\mathrm{MeOH}$ in the presence of triethylamine leads to monocationic complexes $[\mathrm{Zn}(\mathbf{6 2} \cdot \mathbf{H})]\left(\mathrm{ClO}_{4}\right)$, i.e. $\mathbf{B}$ in which the linking $\mathrm{OH}$ group underwent deprotonation to oxygen atom. This complex also binds a guest, although with a lower affinity than the dicationic complex $\mathbf{A}$; as a result $[\mathrm{Zn}(\mathbf{6 2} \cdot \mathbf{H})(\mathrm{G})]\left(\mathrm{ClO}_{4}\right)$ is formed. The exchange rate of guest increases in the order $[\mathrm{Zn}(\mathbf{6 2} \mathbf{a} \cdot \mathbf{H})(\mathrm{G})]^{2+}<[\mathrm{Zn}(\mathbf{6 2} \mathbf{b})(\mathrm{G})]^{+}<[\mathrm{Zn}(\mathbf{6 2 a})(\mathrm{G})]^{+}$, i.e. following the increase of the donor ability of the calixarene-based coordination core; the stronger is the $\mathrm{Zn}$ Lewis acidity, the stronger is the Zn-guest bond and the slower is the exchange rate.

(3) The reaction of $\mathbf{6 2} \mathbf{a} \cdot \mathbf{H}$ and $\mathbf{6 2} \mathbf{b} \cdot \mathbf{H}$ with $\mathrm{Zn}\left(\mathrm{H}_{2} \mathrm{O}\right)_{6}\left(\mathrm{ClO}_{4}\right)_{2}$ in $\mathrm{MeOH}$ in the presence of an anion $\left(\mathrm{X}^{-}=\mathrm{OH}^{-}, \mathrm{Cl}^{-}, \mathrm{N}_{3}^{-}, \mathrm{PhCOO}^{-}\right)$affords neutral complexes $[\mathrm{Zn}(62) \mathrm{X}]$, i.e $\mathbf{C}$ in which the anion $\mathrm{X}^{-}$coordinates $\mathrm{Zn}^{2+}$ from the outside of the cavity. In these complexes calixarene has a partial cone conformation with one imidazole arm released by the metal center. The other imidazole arm, still bound to the metal center, undergoes self-inclusion into the calixarene cavity and fills it. Therefore the formed complex $[\mathrm{Zn}(62) \mathrm{X}]$ is unable to endo-bind guests. Thus the coordination of two anions ( $\mathrm{ArO}^{-}$and $\mathrm{X}^{-}$) decreases the Lewis acidity of zinc to a point that the metal center does not bind a fifth donor, i.e. the complex $[\mathrm{Zn}(62) \mathrm{X}]$ cannot include guests into its cavity. The zinc affinity for a guest decreases in the order: dicationic $\mathbf{A}>$ monocationic $\mathbf{B}>$ neutral $\mathbf{C}$, which does not bind guests at all.

It should be pointed out that the above complexes behave as acid-base switch for guest binding to give $O N-O F F$ system. The dicationic form having the strongest Lewis acidic $\mathrm{Zn}$ center represents the $O N$ state; it includes the small guest G. Deprotonation of the phenol group weakens the $\mathrm{Zn}-\mathrm{G}$ bond; the formed monocationic complex either remains in an $O N$ state or releases $\mathrm{G}$ to give the $O F F$ state. Further addition of a base leads to the full $O F F$ state, i.e. the formation of the neutral complex, with the self-inclusion of the imidazole substituent. The process is reversible, addition of an acid to the neutral complex drives back the equilibria to the $O N$ state. Some features of the above systems are similar to behavior of $\mathrm{Zn}$-peptidases of the astacin and serralysin families, in which the active $\mathrm{Zn}(\mathrm{II})$ site is coordinated to three histidine residues. ${ }^{106}$ 


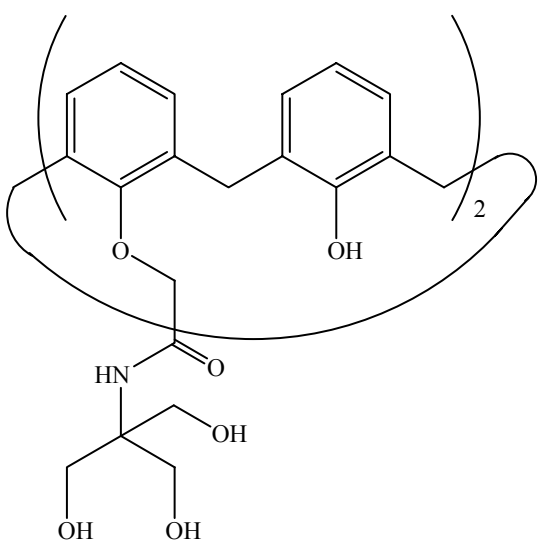

56

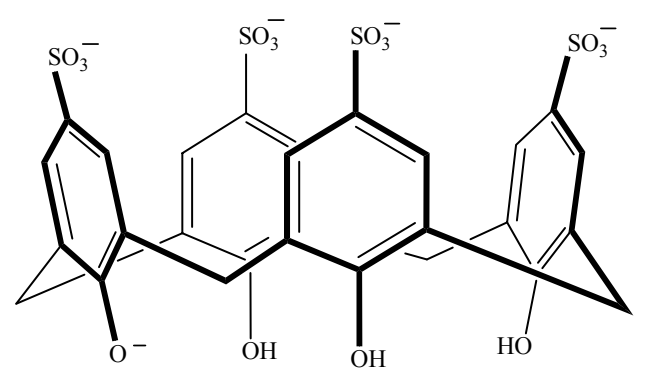

$\|$

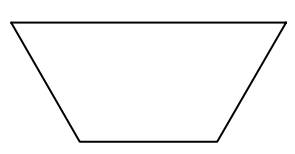

57
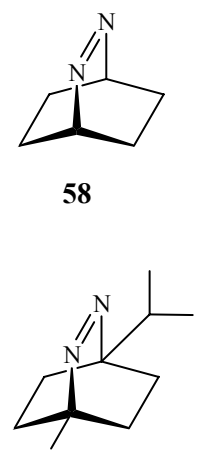

59

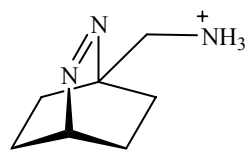

60
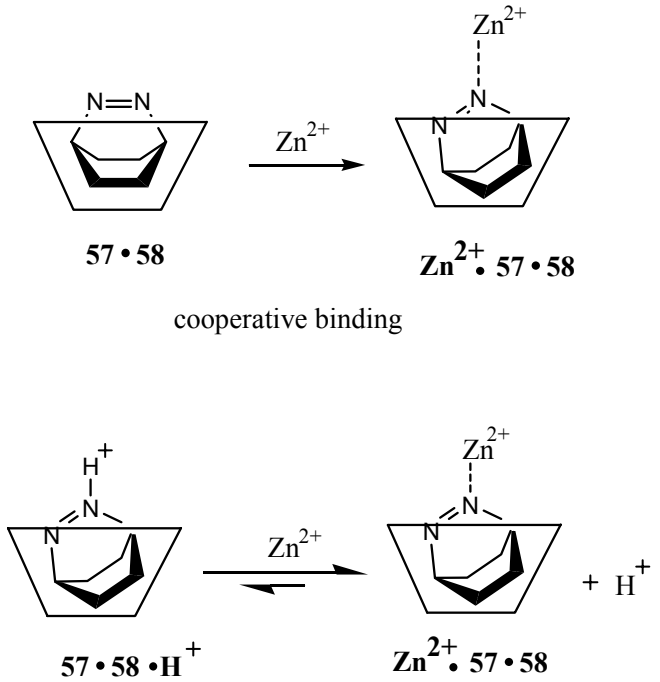

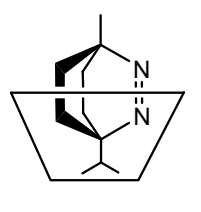

$\mathbf{5 7} \cdot 59$

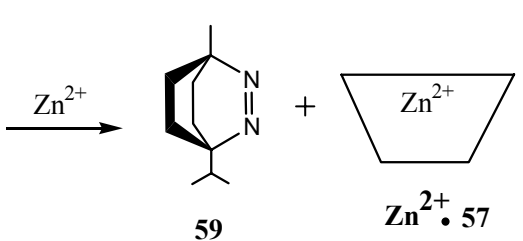

competitive binding

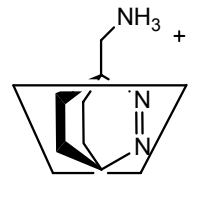

$57 \cdot 60$

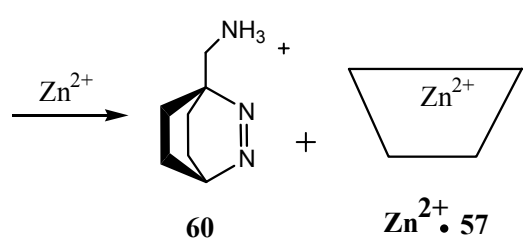

competitive binding 


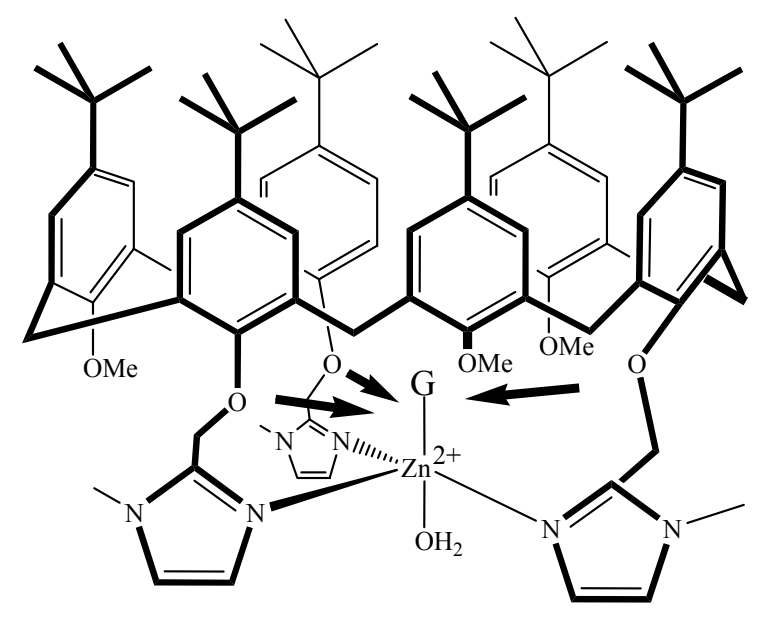

61

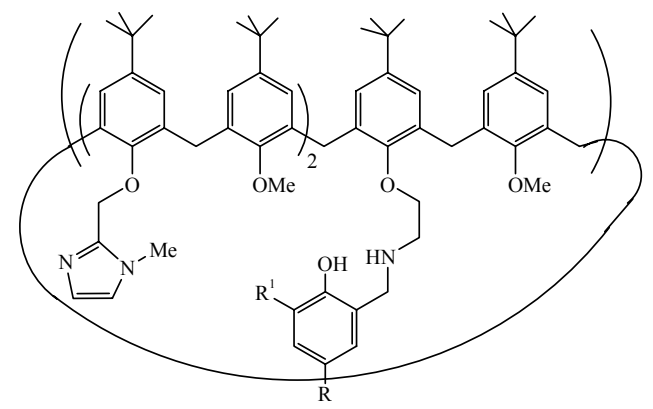

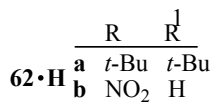

$\|$

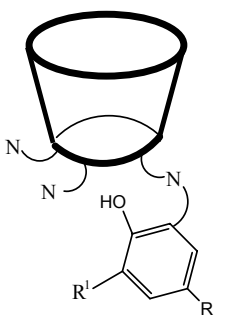

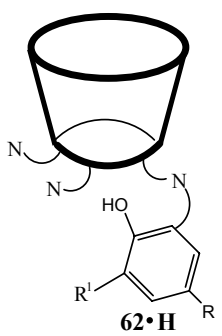

62・ $\mathbf{H}$ for $\mathbf{6 2} \cdot \mathbf{H}\left|\begin{array}{ll}\mathrm{Zn}\left(\mathrm{H}_{2} \mathrm{O}\right)_{6}\left(\mathrm{ClO}_{4}\right)_{2} & \text { for } \mathbf{6 2} \cdot \mathbf{H} \\ \mathrm{MeOH} / \mathrm{Et}_{3} \mathrm{~N}\end{array}\right|$

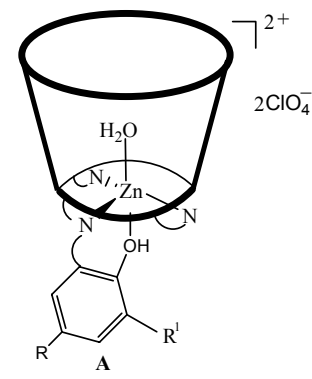

$\left[\mathrm{Zn}(\mathbf{6 2} \mathbf{a} \cdot \mathbf{H})\left(\mathrm{H}_{2} \mathrm{O}\right)\right]\left(\mathrm{ClO}_{4}\right)_{2}$
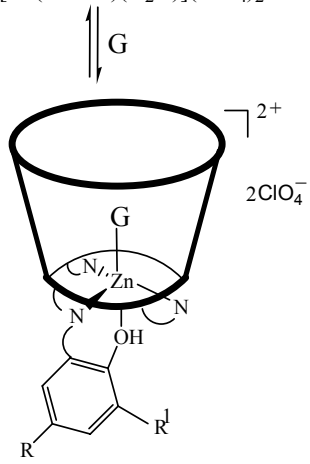

$[\mathrm{Zn}(\mathbf{6 2} \mathbf{a} \cdot \mathbf{H})(\mathrm{G})]\left(\mathrm{ClO}_{4}\right)_{2}$

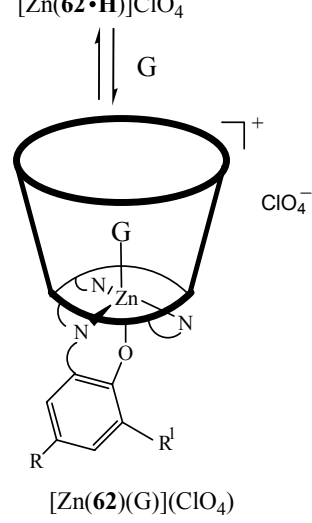

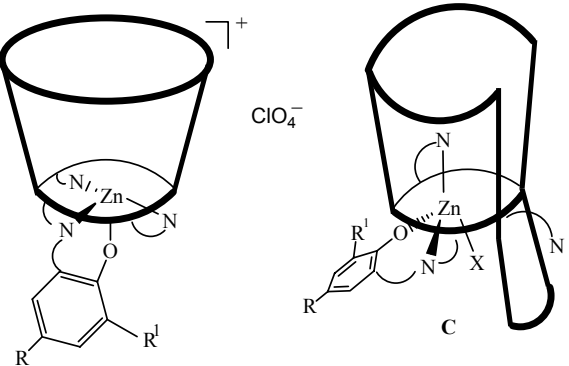

$[\mathrm{Zn}(\mathbf{6 2})(\mathrm{X})]$

$\mathrm{X}=\mathrm{OH}, \mathrm{Cl}, \mathrm{N}_{3}, \mathrm{PhCOO}$

$\mathrm{G}=\mathrm{ROH}, \mathrm{RCN}, \mathrm{RCONH}_{2}$ 


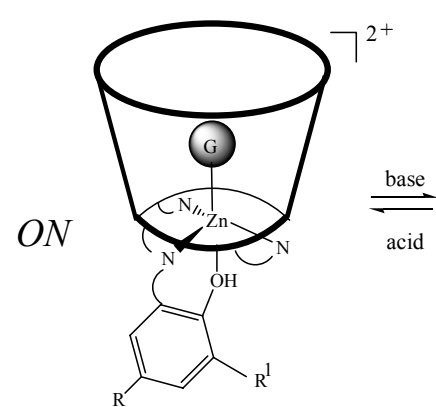

$[\mathrm{Zn}(\mathbf{6 2} \mathbf{H})(\mathrm{G})]^{2+}$

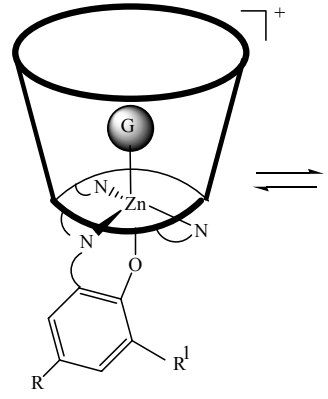

$[\operatorname{Zn}(62 \mathbf{H})(\mathrm{G})]^{+}$

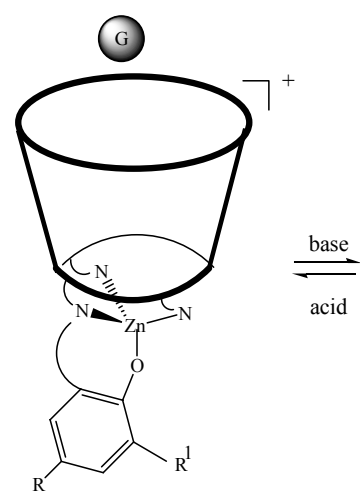

$[\mathrm{Zn}(62)]^{+}$

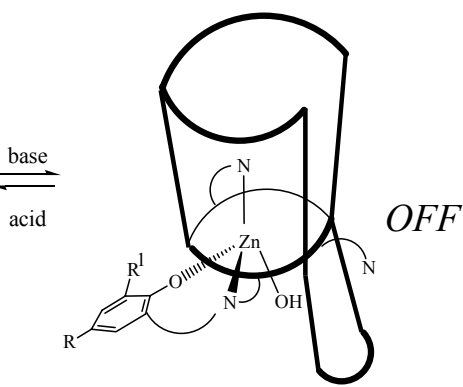

$[\mathrm{Zn}(\mathbf{6 2})(\mathrm{OH})]$

$=\mathrm{G}=\mathrm{H}_{2} \mathrm{O}, \mathrm{DMF}, \mathrm{EtOH}, \mathrm{MeCN}$

\section{Scheme 5}

Complexing properties of calix[6]arene 63, bearing three primary alkylamino arms have been studied. ${ }^{105}$ It was found that $\mathbf{6 3}$ can be structured by strong acids, e.g. TFA to give a polarized receptor 64. Upon this protonation of 63 leading to 64 the three ammonium groups of 63 become sealed together by the counter-anions. Calixarene $\mathbf{6 4}$, having a hydrophobic $\pi$-basic cavity terminating in a tricationic protic site, shows a strong affinity for polar neutral guests $\mathrm{G}$ such as alcohols, amides, ureas or nitriles; their encapsulation yields complexes 65. ${ }^{107-110}$ This behavior is due to the self-assembly of the ion-paired platform, closing the narrow rim of the cavity and freezing the calixarene cone conformation, as well as stabilizing the neutral guests via hydrogen bonding and charge-dipole interactions.

The reaction of $\mathbf{6 3}$ with $\mathrm{Zn}\left(\mathrm{H}_{2} \mathrm{O}\right)_{6}\left(\mathrm{ClO}_{4}\right)_{2}$ in $\mathrm{MeOH}$ affords mononuclear complex 66, whereas reaction with $\mathrm{Zn}\left(\mathrm{H}_{2} \mathrm{O}\right)_{6}\left(\mathrm{ClO}_{4}\right)_{2}$ in $\mathrm{MeOH}$ in the presence of $\mathrm{KOH}$ leads to the dinuclear $\mu$-hydroxo complex 67.

It was found that 65 forms with $\mathrm{Zn}^{2+}$ ion the dinuclear complex 68 . Treatment of 68 with a carboxylic acid or a sulfonamide, i.e. $\mathrm{XH}\left(\mathrm{X}=\mathrm{PhCOO}, \mathrm{AcO}, \mathrm{MeSO}_{2} \mathrm{NH}\right)$ and TEA $(\mathrm{TEA}=$ triethanoloamine) affords complex 69, while treatment of 68 with alkylamine and strong acid, e.g. $\mathrm{RNH}_{2} / \mathrm{TFA}$ leads to complex 70. It is of importance that the asymmetry of an enantiopure amino ligand is transmitted to the calixarene core, in this way the asymmetry of the external ligands is sensed by the guest. Complexes 69 and 70 contain the tetrahedral $\mathrm{Zn}^{+}$ion bound to three amino arms and to an exogenous ligand $\left(\mathrm{X}\right.$ or $\left.\mathrm{RNH}_{2}\right)$ protruding outside the cavity. As a result, the metal ion structures the calixarene core, constraining it in a cone conformation suitable for guest inclusion. The formed calixarene cone acts as a polarized receptor; its host properties can be allosterically tuned by the environment via the binding of external ligands to $\mathrm{Zn}^{2+}$ ion. In the case of the electron rich external ligand, the receptor is less polarized, and highly sensitive to the hydrogen bonding ability of the guest, however in the case of less electron rich external 
ligand, the receptor becomes more polarized, and more sensitive to the dipole moment of the guest, i.e. the binding of dipolar molecules is more efficient. These properties are different than those of funnel $\mathrm{Zn}$ complexes, e.g. 61, in which the coordination link of $\mathrm{Zn}^{2+}$ with the guest plays a dominant role. The above observations are of interest in the search for artificial enzymes. ${ }^{105}$

In calix[6]tren $\mathbf{7 1}$ the cone conformation is restricted by presence of the tren cap. The calix[6]tren 71 is an effective receptor with the cavity consisting of highly $\pi$-basic aromatic walls; the grid-like nitrogenous cap is also highly basic. The host properties of 71 can be tuned by the environment, more or less basic or by presence of metal ions. As a result, $\mathbf{7 1}$ may include cationic species such as metal ions or ammoniums as well as various neutral molecules. The reaction of 71 with $\left[\mathrm{Zn}\left(\mathrm{ClO}_{4}\right)_{2}\left(\mathrm{H}_{2} \mathrm{O}\right)_{6}\right.$ and the guest $\mathrm{G}$ yields the complex $\mathrm{Zn}^{2+} \cdot \mathbf{7 1}^{\cdot} \cdot \mathrm{G}$. ${ }^{104}$

Complexes $\mathrm{Zn}^{2+} \cdot \mathbf{7 1} \cdot \mathrm{G}$, where the guest $\mathrm{G}=\mathrm{ROH}, \mathrm{RCN}$, DMF or $\mathrm{RCONH}_{2}$ are highly resistant; the addition of $\mathrm{AcOH}, \mathrm{MeI}, \mathrm{Et}_{3} \mathrm{~N}$ or a strong base such as $\mathrm{NBu}_{4} \mathrm{OH}$ does not result in deprotonation of the guest or decoordination of $\mathrm{Zn}^{2+}$. This high robustness is due to both a strong chelate effect of the tren cap and a cavity-controlled access to the metal center.
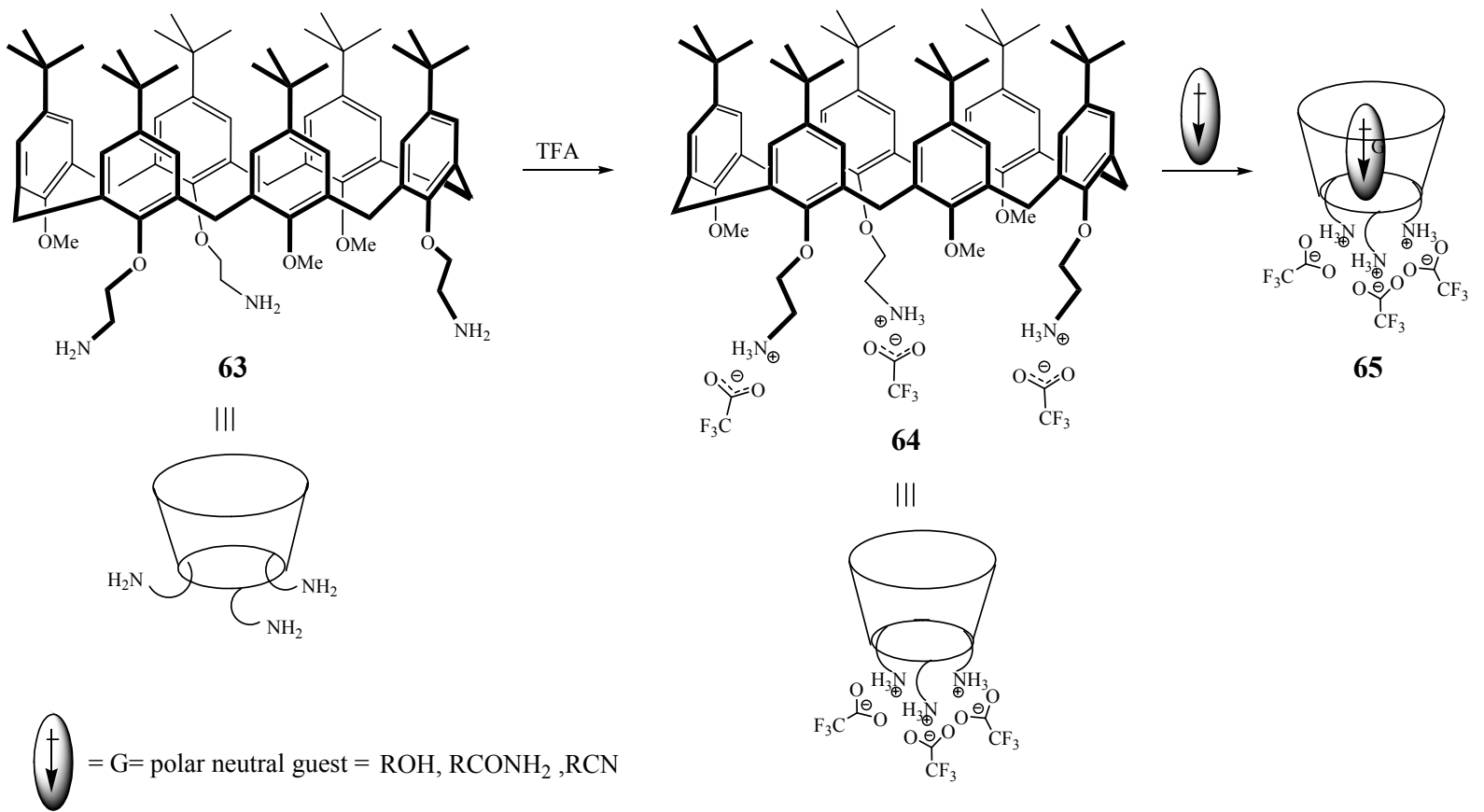

65

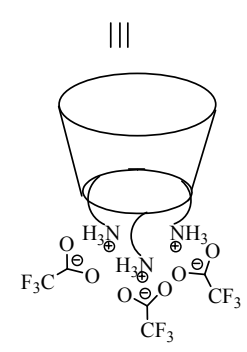



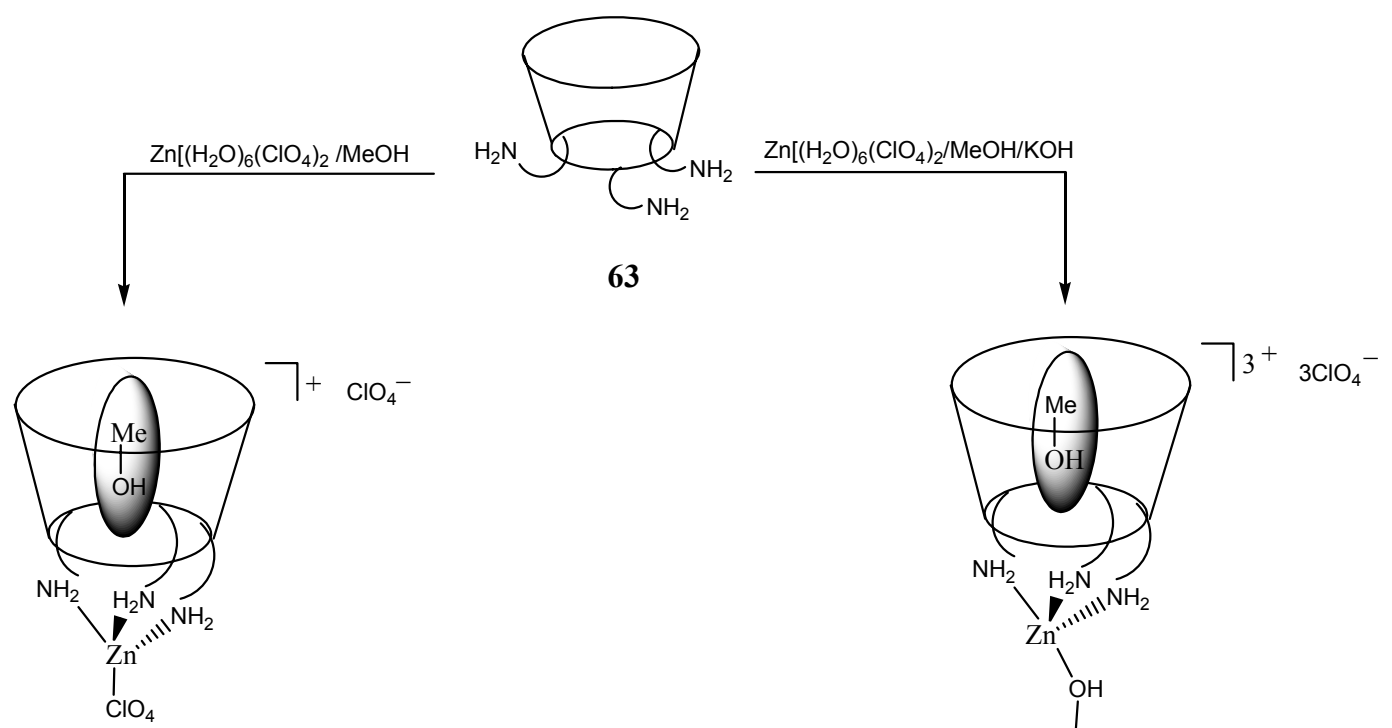

66
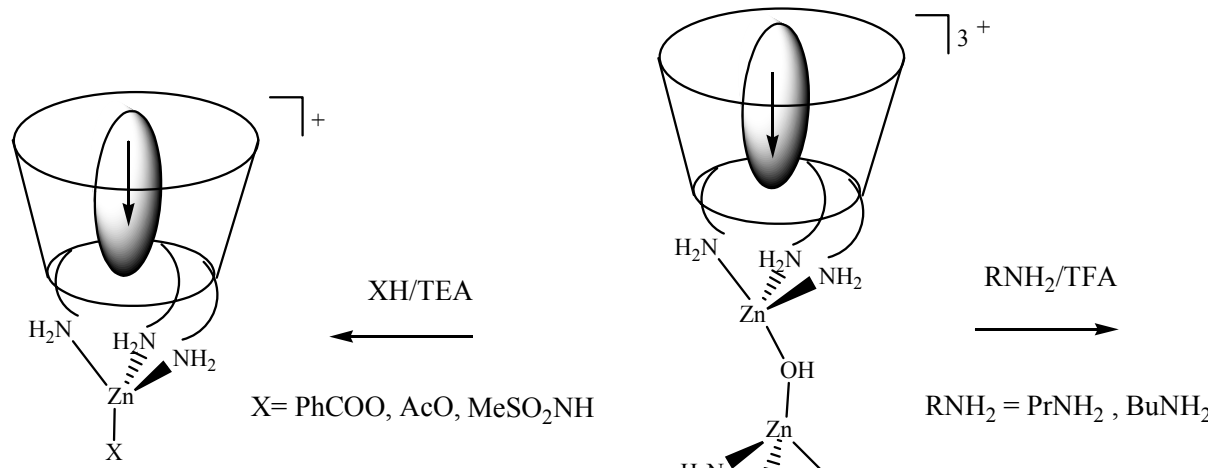

69

$=\mathrm{G}=$ polar neutral guest
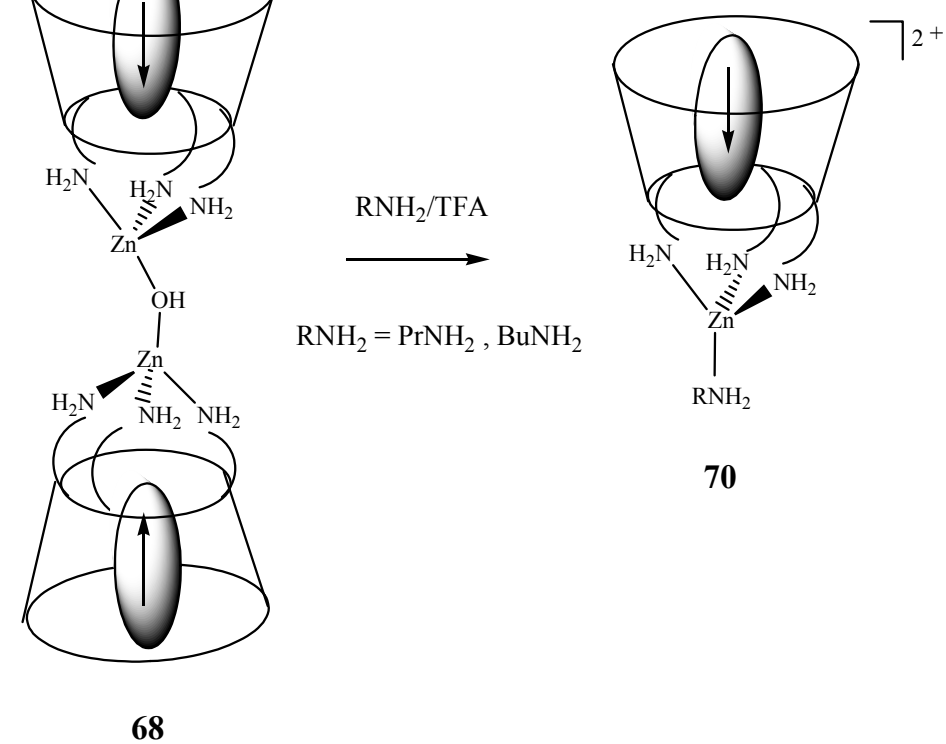

70 

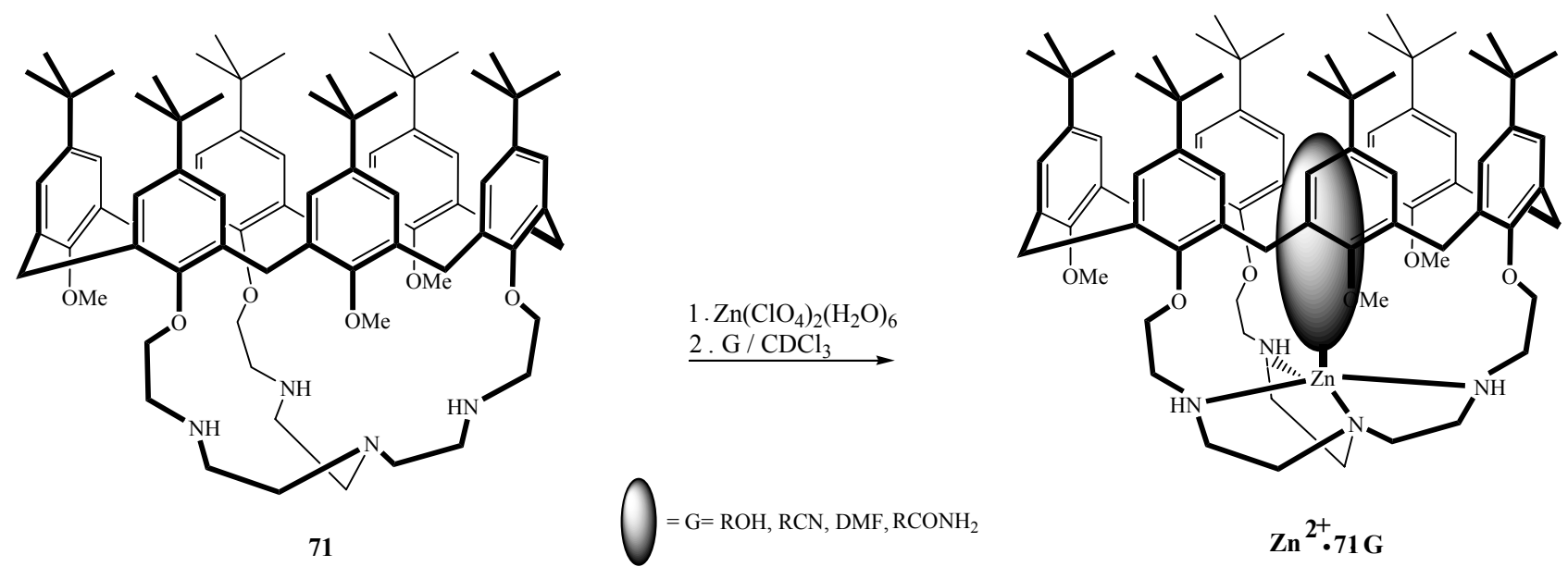

Scheme 6

Bimetallic zinc complexes are of interest in catalytic processes involving asymmetric organic syntheses and enzymatic reactions. Bimetallic zinc complexes usually act as catalysts in organic and enzymatic processes by a tandem participation of both zinc atoms. The catalytic activity of calixarenes containing two zinc centres in close proximity to each other, has been studied. ${ }^{111}$ For this purpose bimetallic zinc complex 72a was used as a catalyst of the ring-opening polymerization of L-lactide 73. The reaction leads to complex 74a which by precipitation with $n$ hexane affords poly(lactic acid) PLA and free 72a. In this process PLA with high molecular weight and a low degree of polydispersity is obtained; it was observed that the catalytic activity of 72b is higher than that of 72a. It should be pointed out that PLA is a polymer promising for its biocompatible and biodegradable properties.

It was established that the catalytic activity of $\mathbf{7 2}$ depends only on the external alkyl zinc group serving as an initiator, and is independent on the alkyl zinc group situated inside the calixarene cavity; this zinc atom, immersed in the calixarene cavity does not participate in catalysis. The above results are an example of the single-site catalytic mechanism of a bimetallic zinc calixarene complex. ${ }^{111,112}$ It should be noted that the calixcrown bimetallic zinc complex $\mathbf{7 5}$ also catalyzes ring-opening polymerization of L-lactide to give the complex 76; this process is a confirmation of the zinc single-site catalytic mechanism.

The reaction of the bimetallic zinc complex 77 with $\mathrm{B}\left(\mathrm{C}_{6} \mathrm{~F}_{5}\right)_{3}$ in benzene, followed by the addition of a bidentate ligand $\mathrm{L}$, such as bipyridine or phenanthroline affords bimetallic complexes 78, whereas upon treatment with wet trifluoroborane etherate the monometallic complex 79 is formed. ${ }^{113,114}$

The single-crystal X-ray analysis of $\mathbf{7 9}$, obtained from the toluene solution, shows that $\mathrm{Zn}^{2+}$ is situated at the centre of an octahedron, with four calixarene oxygen atoms in the equatorial plane. Two water molecules are localized at axial positions, one of them being immersed in the calixarene cavity. 


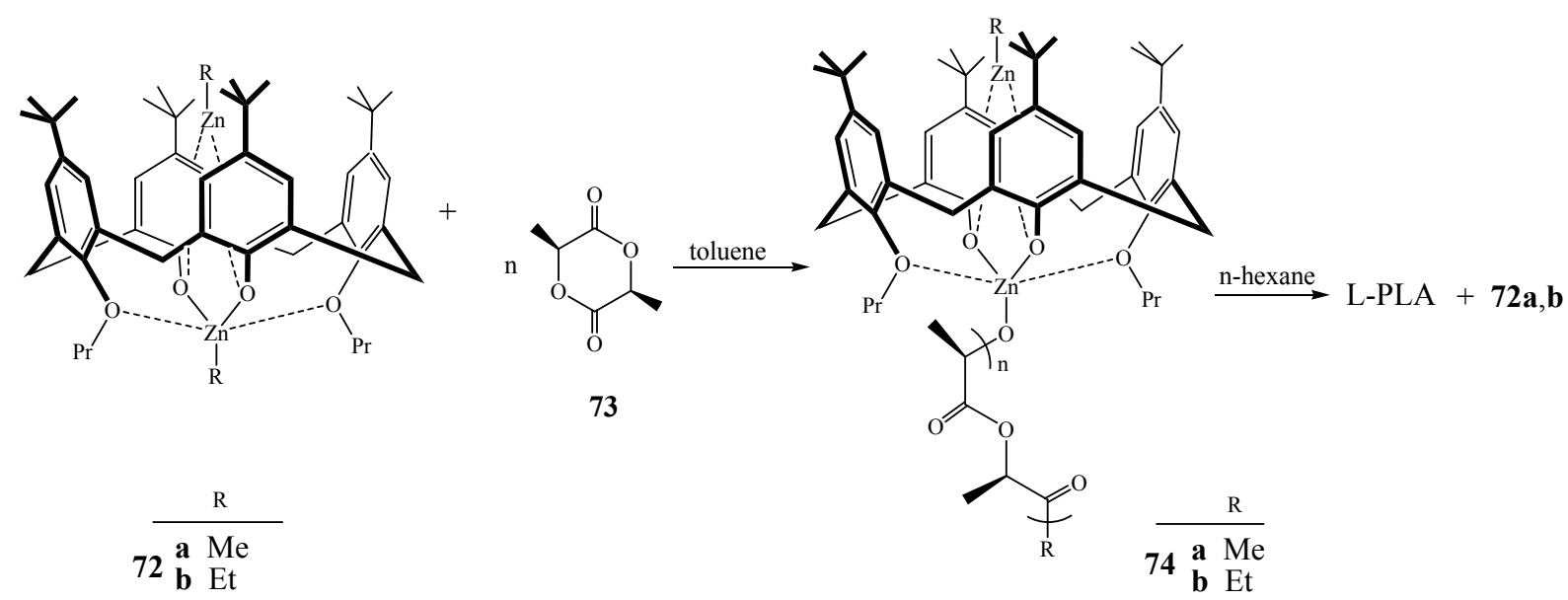

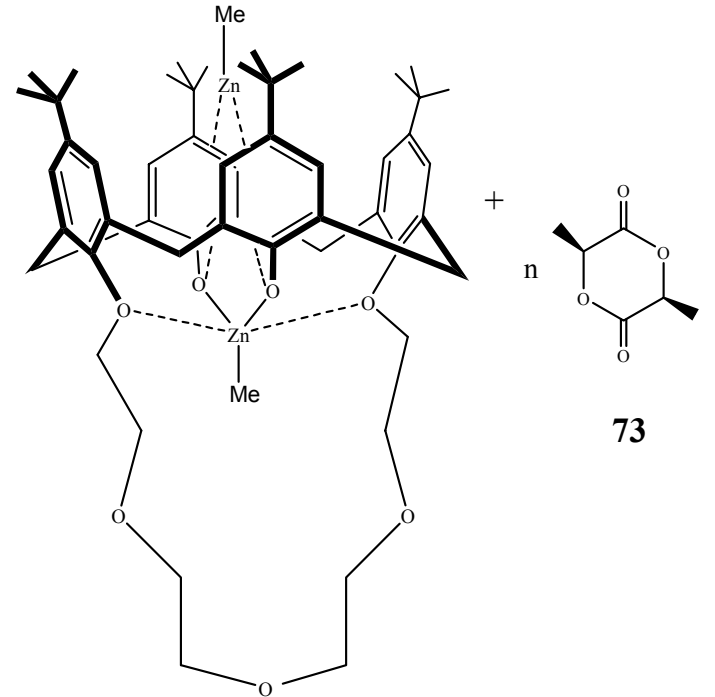

75

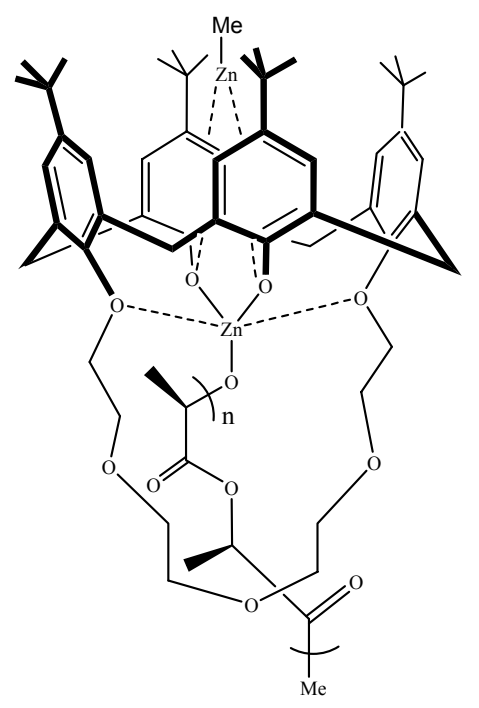

76 


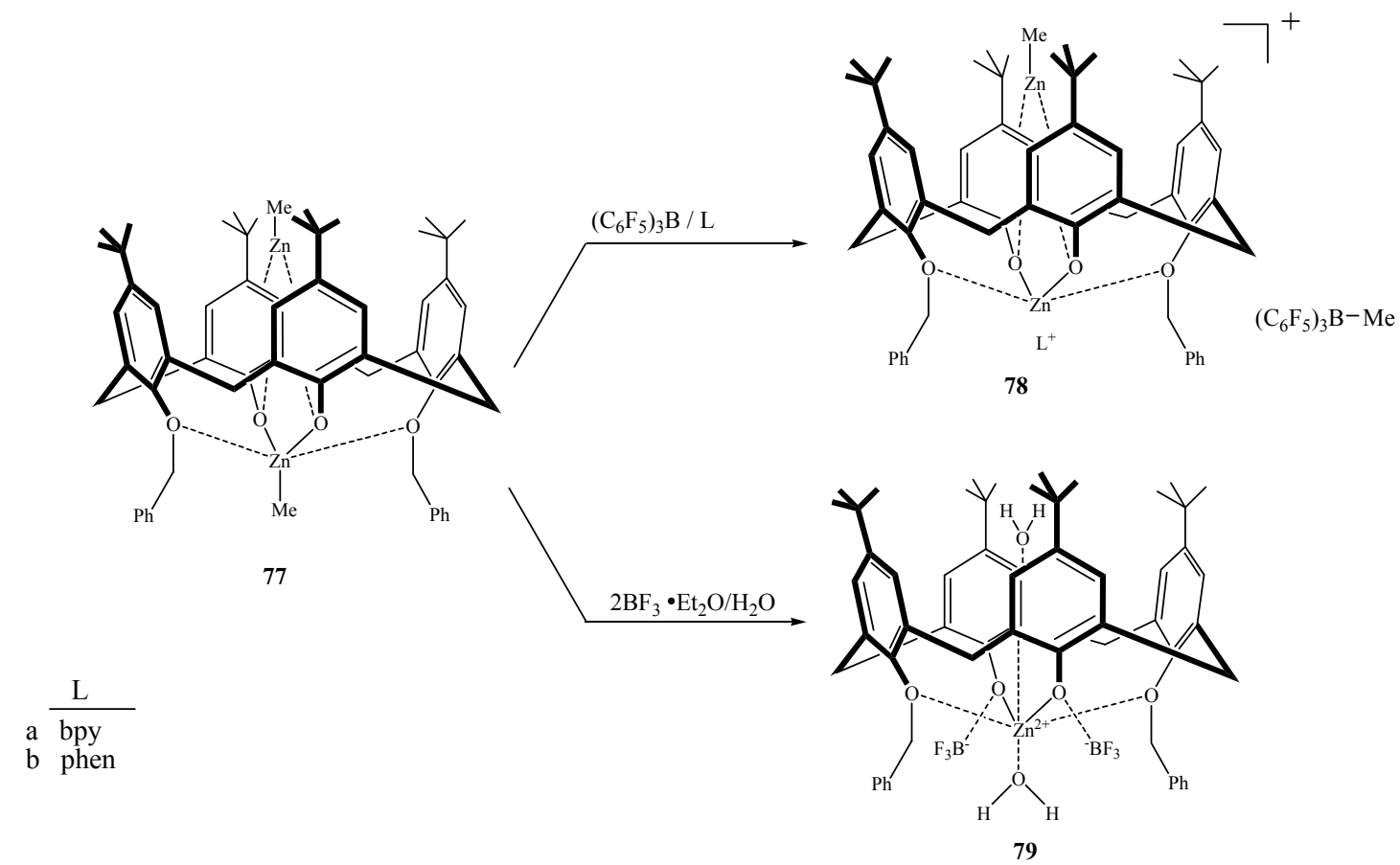

Scheme 7

\section{Calixarene complexes with cadmium ions}

Cadmium is used in industry, e.g. in the production of pigments and anticorrosive coatings, alloys and batteries; due to the presence in natural waters, its determination with the use of simple, disposable devices is necessary. Cadmium is toxic to plants and humans, its toxicity involves the strong affinity to thiol groups, displacing the biologically important zinc. ${ }^{115}$ Examples of works dealing with calixarene cadmium complexes ${ }^{49}$ are described below.

In the study of calix[5] arenes, ${ }^{116-119}$ the complexing properties of calix[5] arene 80b with metal ions have been determined. The complexation of calix[5]arene $\mathbf{8 0 b}$ with $\mathrm{Cd}^{2+}$ and $\mathrm{Hg}^{2+}$ ions was investigated by conductometric titrations in methanol and in acetonitrile; it was found that $1: 1$ complexes are formed, the binding constant of $\mathrm{Hg}^{2+}$ complex being higher than that of the $\mathrm{Cd}^{2+}$ complex. ${ }^{120}$ It is noteworthy that analogous tetrameric calix[4]arene 80a shows more efficient binding ability than $\mathbf{8 0 b}$ towards $\mathrm{Cd}^{2+}$ and $\mathrm{Hg}^{2+}$ ions. ${ }^{120}$

In the search for cadmium sensors it was found that calixarenes $\mathbf{8 1}$ and $\mathbf{8 2}$ may serve for modification of screen-printed carbon electrodes for complexation of $\mathrm{Cd}^{2+}$ traces at open circuit. ${ }^{115}$ It should be noted that $\mathbf{8 2}$ has higher configurational stability than $\mathbf{8 1}$, since $\mathbf{8 2}$ contains $t$ butyl substituents at the wide rim, and ethylthio substituents at the narrow rim, therefore $\mathbf{8 2}$ has greater propensity to the cone conformation. Since $\mathbf{8 1}$ does not bear these groups, it may move through the four possible conformations, i.e. cone, partial cone, 1,2- and 1,3-alternate. 
The screen-printed carbon electrodes modified with $\mathbf{8 1}$ and $\mathbf{8 2}$ are able to accumulate $\mathrm{Cd}^{2+}$ ions; the better results have been obtained in the case of $\mathbf{8 2}$. It should be noted that the screen-printed sensor modified with $\mathbf{8 2}$ may be used for the trace determination of $\mathrm{Cd}^{2+}$ in environmental water samples. ${ }^{115}$

It was found that calixarene $\mathbf{8 3}$, bearing four allyl groups includes $\mathrm{Cd}^{2+}$ and $\mathrm{Tl}^{+}$ ions. ${ }^{121}$ This behavior served for building of glassy carbon electrode coated with LangmuirBlodgett (LB) film of 83, able to simultaneous determination of traces of $\mathrm{Cd}^{2+}$ and $\mathrm{Tl}^{+}$in environmental water; indium does not respond to the above LB film electrode.

The method involves chelation of metal ions from solution on the surface of glassy carbon electrode coated with $\mathbf{8 3}$, reduction of the accumulated metal ions and electrochemical stripping of the reductive material back into solution. The electrode can be used to simultaneous determination of $\mathrm{Cd}^{2+}$ and $\mathrm{Tl}^{+}$. This process is explained by hard soft acid and base (HSAB) principle, $\mathrm{Cd}^{2+}$ and $\mathrm{Tl}^{+}$ions being soft acids, and allyl group and benzene ring being soft bases. It should be pointed out that the above electrode is environment friendly since it replaces current mercure electrode in environmental analysis.

The chromogenic calixarene 84 containing four azo groups may serve for detection of $\mathrm{Cd}^{2+}$ and $\mathrm{Cu}^{2+}$ ions, for this purpose the optical fiber sensor based on $\mathbf{8 4}$ has been built. ${ }^{122}$ The detection of the above ions involves the covering of the optical fiber core by a transparent polymer containing a complexing agent; its absorption properties are modified in the presence of the considered ions. The trapping of the ion in the polymeric cladding, i.e. in the cavities of the chelating molecules induces a variation of the light power transmitted along the fiber.

The detection of metal ions by optical fiber is advantageous as compared to that performed by use of electrochemical techniques, since the probe is miniaturized and no effects of the ionic strength nor of the medium conductivity occur. The method is simple, the detection is done in situ, at ambient temperature and under atmospheric pressure; only source of light, optical fiber and detector are required. ${ }^{122}$

Complexing properties of chromogenic calixarene 85, bearing two azo moieties towards $\mathrm{Cd}^{2+}$ ion has been studied by UV/Vis spectroscopy. The formation of the complex occurs in polar solvents like acetonitrile, acetone, methanol and $\mathrm{DMF}$, but not in less polar solvents like $\mathrm{CHCl}_{3}$ or THF. The most suitable solvent showed to be acetonitrile, ensuring efficient complexation without formation of aggregates. The obtained complexes have 1:1 stoichiometry. ${ }^{123}$ 


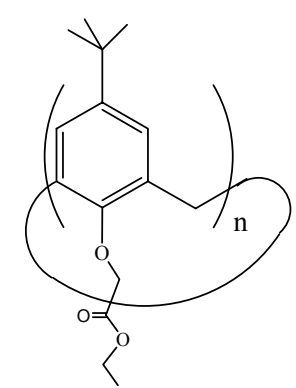

$\begin{array}{rr}\mathrm{80} & \mathbf{n} \\ \mathbf{b} & 5\end{array}$

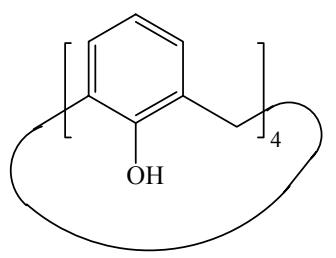

81

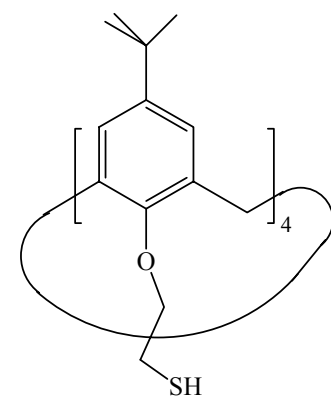

82

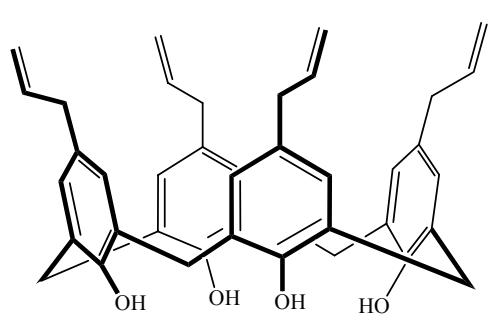

83

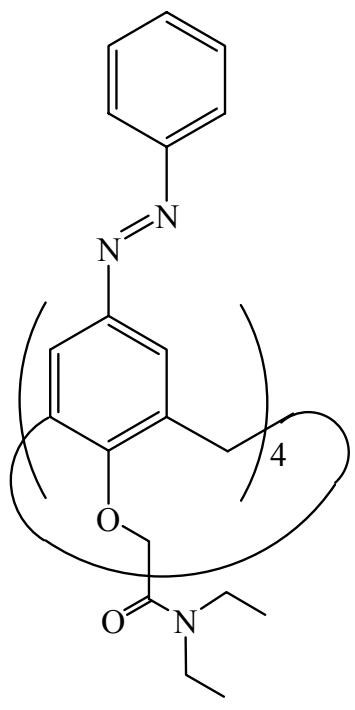

84

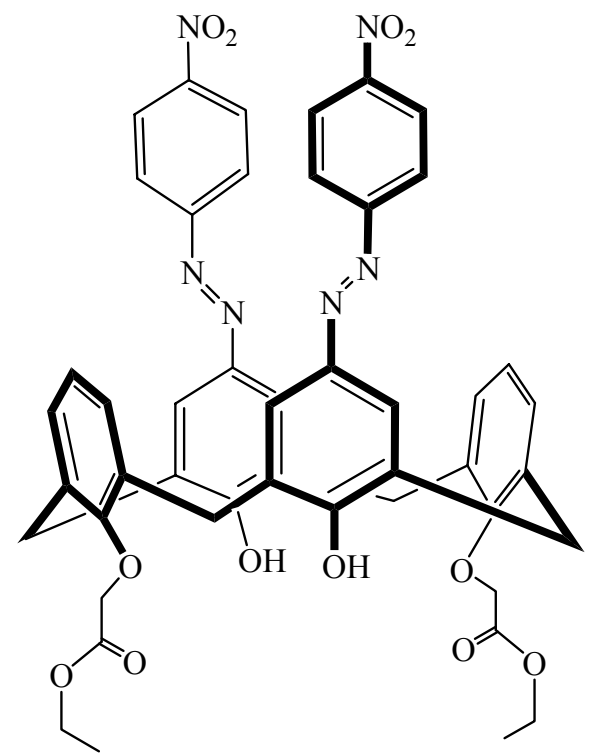

85

\section{Scheme 8}

\section{Calixarene complexes with mercury ions}

Mercury is a toxic metal dangerous for human health, its contamination is widespread in the environment. Mercury pollution arises from gold mining and combustion of fossil fuels, as well as from volcanic emissions. A growing attention is paid today to the detection of mercuric ion in the environment and in biological samples. ${ }^{124}$ Calixarene complexes with mercury ions are a topic of numerous works. ${ }^{71,125,126}$

It was observed that thiohexyl oligophenylene substituted calixarenes 86a,b form 1:1 complexes with $\mathrm{Hg}^{2+}$ and with $\mathrm{Ag}^{+}$ions. The association constants were estimated by use of fluorescent titrations in $\mathrm{CHCl}_{3} / \mathrm{MeOH}$, this value for $\mathrm{Hg}^{2+} \cdot \mathbf{8 6 a}$ being higher than that for 
$\mathrm{Hg}^{2+}$.86b. ${ }^{127}$ The ${ }^{1} \mathrm{H}$ NMR spectroscopy results show that $\mathrm{Hg}^{2+}$ or $\mathrm{Ag}^{+}$ion is cooperatively bound by the two opposite sulfur atoms of 86a leading to conformationally stable pinched cone structure. It is noteworthy that the binding affinities of $\mathbf{8 6 a}, \mathbf{b}$ toward $\mathrm{Hg}^{2+}$ and $\mathrm{Ag}^{2+}$ ions are stronger than those of the corresponding monomeric units due to the cooperation effect of the proximate fluoroionophores.

In the study of complexing properties of calixarenes bearing two dansyl groups it was observed that $\mathbf{8 7}$ is sensitive towards $\mathrm{Hg}^{2+}$ ions and exhibits high selectivity. Having in view these properties of $\mathbf{8 7}$, its analogue $\mathbf{8 8}$, showing an additional grafting ability on the silica surface was designed.

In order to build an optical sensor device, calixarene $\mathbf{8 8}$ was grafted on SBA-15 mesoporous silica and the fluorescence properties of the obtained material 88.SBA-15 have been investigated. 128 The detection limit is determined by a strong quenching of fluorescence upon the $\mathrm{Hg}^{2+}$ complexation. It was established that 88.SBA-15 reversibly detects $\mathrm{Hg}^{2+}$ ions in water and does not interfere with $\mathrm{K}^{+}, \mathrm{Ca}^{2+}, \mathrm{Zn}^{2+}$ and $\mathrm{Cd}^{2+}$ ions; it should be pointed out that the response is rapid.

It was found that the complexing ability of calixarene $\mathbf{8 9}$ toward metal cations is higher in $\mathrm{MeCN}$ than in DMF and MeOH. In MeCN 89 recognizes $\mathrm{Hg}^{2+}$ over $\mathrm{Li}^{+}, \mathrm{Na}^{+}, \mathrm{Ag}^{+}, \mathrm{Ca}^{2+}, \mathrm{Cu}^{2+}$ and $\mathrm{Pb}^{2+}$ ions, while in DMF and in $\mathrm{MeOH} 89$ interacts only with $\mathrm{Hg}^{2+}$ and $\mathrm{Ag}^{+}$. In all cases the $1: 1$ complexes are formed. ${ }^{129}$

The study of the strength of complexation of $\mathbf{8 9}$ with $\mathrm{Hg}^{2+}$ and $\mathrm{Ag}^{+}$in dependence of solvent has shown that for $\mathbf{8 9}$ and $\mathrm{Hg}^{2+}$ the strength of complexation decreases in the order $\mathrm{MeCN}>$ $\mathrm{DMF}>\mathrm{MeOH}$ while for $\mathbf{8 9}$ and $\mathrm{Ag}^{+}$this sequence is $\mathrm{MeOH}>\mathrm{DMF}>\mathrm{MeCN}$. Due to the inclusion of $\mathrm{MeCN}$ in the hydrophobic cavity of $\mathbf{8 9}$, the hydrophilic cavity of the resulting complex 89. $\mathrm{MeCN}$ becomes more receptive to include metal cations than the cavity of free 89; this behavior results from the allosteric effect. ${ }^{129}$

One should mention that in MeCN 89 does not include $\mathrm{Cd}^{2+}$ ion, while 80a does; this behavior is explained by the fact that the cavity of $\mathbf{8 0 a}$ is larger than that of $\mathbf{8 9}$ due to higher electrostatic repulsion of pendant arms of 80a resulting from the presence of four carbonyl groups, therefore the cavity of $\mathbf{8 0 a}$ is more open and, as a result, more able to receive $\mathrm{Cd}^{2+}$ ion than the cavity of $\mathbf{8 9} .{ }^{129}$

The complexation of calixarenes $\mathbf{8 9}$ and $\mathbf{9 0}$ toward $\mathrm{Hg}^{2+}$ and $\mathrm{Ag}^{+}$ions in a series of solvents have been investigated. The obtained thermodynamic data were used to assess the effect of solvation of these compounds on their complexing properties. ${ }^{98,130}$

Solubilities and derived Gibbs energies of solutions of 89 and 90 in various solvents have been reported. Solvation of $\mathbf{8 9}$ and $\mathbf{9 0}$ in one medium relative to another was analyzed from their standard transfer Gibbs energies using acetonitrile as the reference solvent. The standard solution enthalpies were determined for mercury and silver salts in acetonitrile, methanol and DMF. These data have been used to derive their transfer enthalpies from one medium to another.

It was found that the extent of complexation of $\mathbf{8 9}$ and 90 with metal cations in different media is not only controlled by the solvation changes of the free cation in various solvents, but 
also is controlled by the solvation of the ligand and of the metal-ion complex in these solvents. The selectivity of 90 for $\mathrm{Hg}^{2+}$ relative to $\mathrm{Ag}^{+}$in $\mathrm{MeCN}$ is reversed in $\mathrm{MeOH}$ and lost in DMF.

Solubility data were used to calculate the standard Gibbs energies of solution. For 89 the strength of solvation decreases in the order: $n-\mathrm{BuOH}>\mathrm{DMF}>\mathrm{EtOH}>\mathrm{MeCN}>\mathrm{PC}>\mathrm{MeOH}$. For 90 this sequence is as follows: $n$ - $\mathrm{BuOH}>\mathrm{DMF}>\mathrm{MeCN}>\mathrm{EtOH}>\mathrm{PC}>\mathrm{MeOH}(\mathrm{PC}=$ propylene carbonate). It was found that the solvation of $\mathbf{8 9}$ is higher than that of $\mathbf{9 0} .^{130}$

In the study of calixarenes bearing arylazo and allyl groups at the wide rim, forming complexes with transition metal ions it was found that 91 -93 show metal-chelating properties. Calixarenes 91a-93b are very good chromogenic ionophores, especially for $\mathrm{Hg}^{2+}$; the complexation of $\mathrm{Hg}^{2+}$ by 91b-93b in methanol/chloroform is visible to the naked

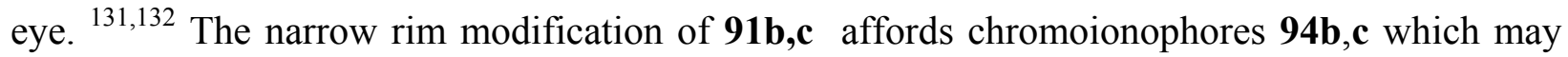
also be used in metal ion detection. ${ }^{131}$ One should mention that synthesized in the reported work compounds 92-94 are colored (92a, 93a orange; 92b, 93b, 94b yellow and 92c, 94c red).

The stoichiometry of complexes of all above calixarenes with metal ions was shown to be 1:1. Calixarene 91b forms with $\mathrm{Hg}^{2+}$ the complex $\mathrm{Hg}^{2+} \cdot 91 \mathbf{b}$. The binding strength of the investigated calixarenes toward $\mathrm{Hg}^{2+}$ decreases in the order 91b $>91 \mathbf{a}>93 \mathrm{~b}>92 \mathrm{~b}>93 \mathrm{a} \sim 92 \mathrm{a}$ $>94 b>>91 c$. The selectivity of $91 b$ toward cations decreases in the order $\mathrm{Hg}^{2+}>\mathrm{Cu}^{2+}>\mathrm{Cr}^{3+}>$ $\mathrm{Ni}^{2+}$

Calixarenes 95-98 are yellow; they form 1: 1 complexes with $\mathrm{Hg}^{2+}$ ion, this process being connected with color changes. The association constants of investigated receptors with $\mathrm{Hg}^{2+}$ decrease in the order $95>96>97 \mathbf{a}>98 \mathbf{a} .{ }^{133}$ The $p$-allyl and $p$-methoxyphenylazo groups take part in the recognition of $\mathrm{Hg}^{2+}$ ion; calixarene 95, containing three $p$-methoxyphenylazo groups binds $\mathrm{Hg}^{2+}$ stronger than 96 containing two $p$-methoxyphenylazo groups, as it is seen in the association constant of 95 higher than that of 96 . Calixarenes 95 and 96 have one and two allyl groups, respectively, whereas 97a and 98a have one and two thioacetoxypropyl groups, respectively, therefore the binding of $\mathrm{Hg}^{2+}$ ion by 95 and 96 is stronger than in the case of $96 \mathbf{a}$ and $98 \mathrm{a}$. The possible binding modes for $\mathrm{Hg}^{2+} .95$ and $\mathrm{Hg}^{2+} .96$ have been proposed.

Among numerous techniques for $\mathrm{Hg}^{2+}$ screening, the fluorescent chemosensors are receiving recently a considerable attention due to their selectivity and simple construction. ${ }^{134-137}$ Fluorescent chemosensors are mainly based on photoinduced electron transfer (PET), metal-ligand charge transfer (MLCT), intramolecular charge transfer (ICT), ${ }^{138,139}$ excimer/exciplex formation, ${ }^{140,141}$ imine isomerisation ${ }^{142}$ and fluorescence resonance energy transfer (FRET). ${ }^{143,144}$

It should be pointed out that FRET is today of a great interest for possibility of its use in optical therapy and in cell physiology, as well as in a selective sensing toward molecular or ionic species. ${ }^{145}$ FRET is an excited-state energy interaction between two fluorophores in which an excited energy donor transfers energy to an energy acceptor without photoemission. Many chemosensors are based on a FRET signal mechanism. ${ }^{143,144}$ 
In the study of calixarenes acting as chemosensors towards cations and anions, a calixarene-based chemosensor 99 which functions as $\mathrm{Hg}^{2+}$-induced FRET from the pyrenyl excimer (energy donor) to rhodamine unit (energy acceptor) was reported. ${ }^{124,146,147}$ Chemosensor 99 is a $N$-tripodal species consisting of two calixarene units, each bearing one pyrenyl group and a rhodamine B unit in a spirolactam form. The pyrenyl groups of neighboring calixarene units are planar, involving a $\pi-\pi$ stacking interaction between them. The calixarene units of $\mathbf{9 9}$ are flexible, this fact can easily lead to the excimer emission. The excimer emission of pyrenyl and the fluorescence absorption of ring-opened rhodamine have a spectral overlap enabling the functionality of 99 as a FRET chemosensor if the pyrenyl unit is excited.

Addition of $\mathrm{Hg}^{2+}$ ion to the MeCN solution of $\mathbf{9 9}$ leads to the ring opening of the rhodamine spirolactam moieties with a FRET-ON signal mechanism and the energy transfer from pyrenyl excimer (energy donor) to rhodamine (energy acceptor). It is noteworthy that in the absence of $\mathrm{Hg}^{2+}$ ion, the energy transfer is impossible due to the spirolactam structure of the rhodamine unit (FRET-OFF). Addition of $\mathrm{Hg}^{2+}$ to the solution of 99 results in the formation of the 1:1 complex $\mathbf{H g}^{2+} .99$ and in a considerably enhanced fluorescence emission (FRET-ON). ${ }^{124}$
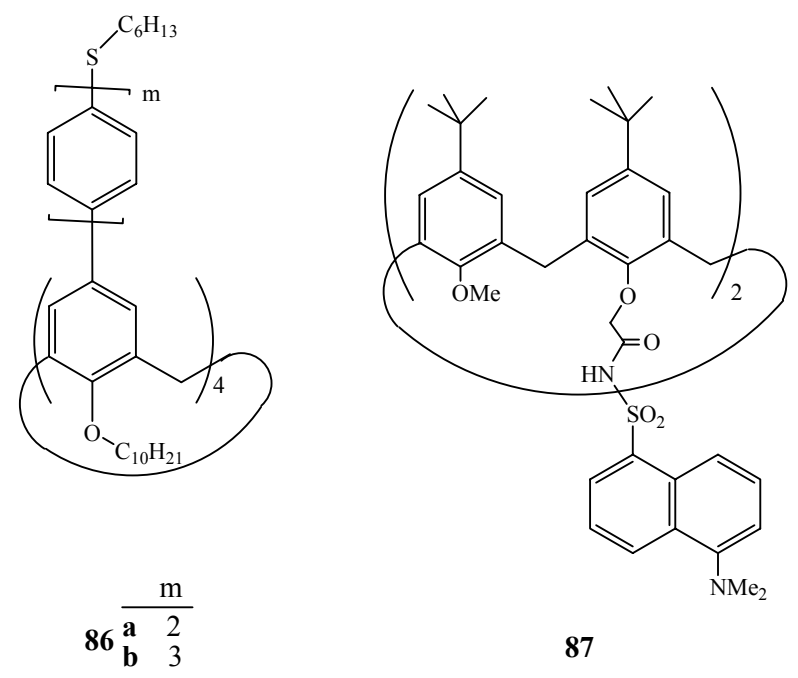

87

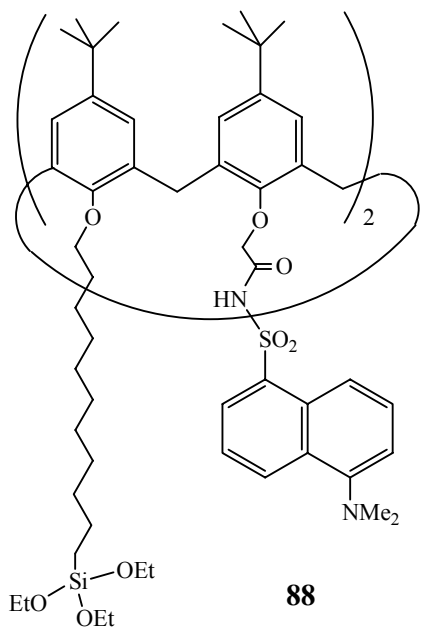

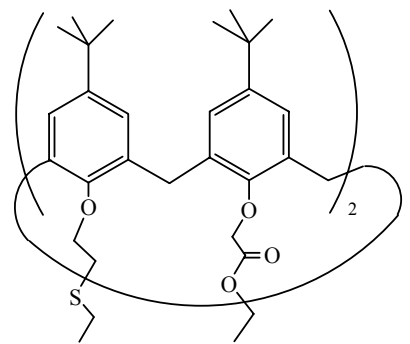

89

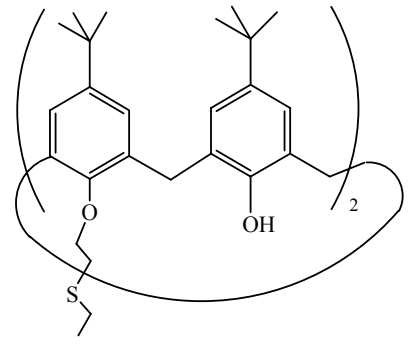

90 

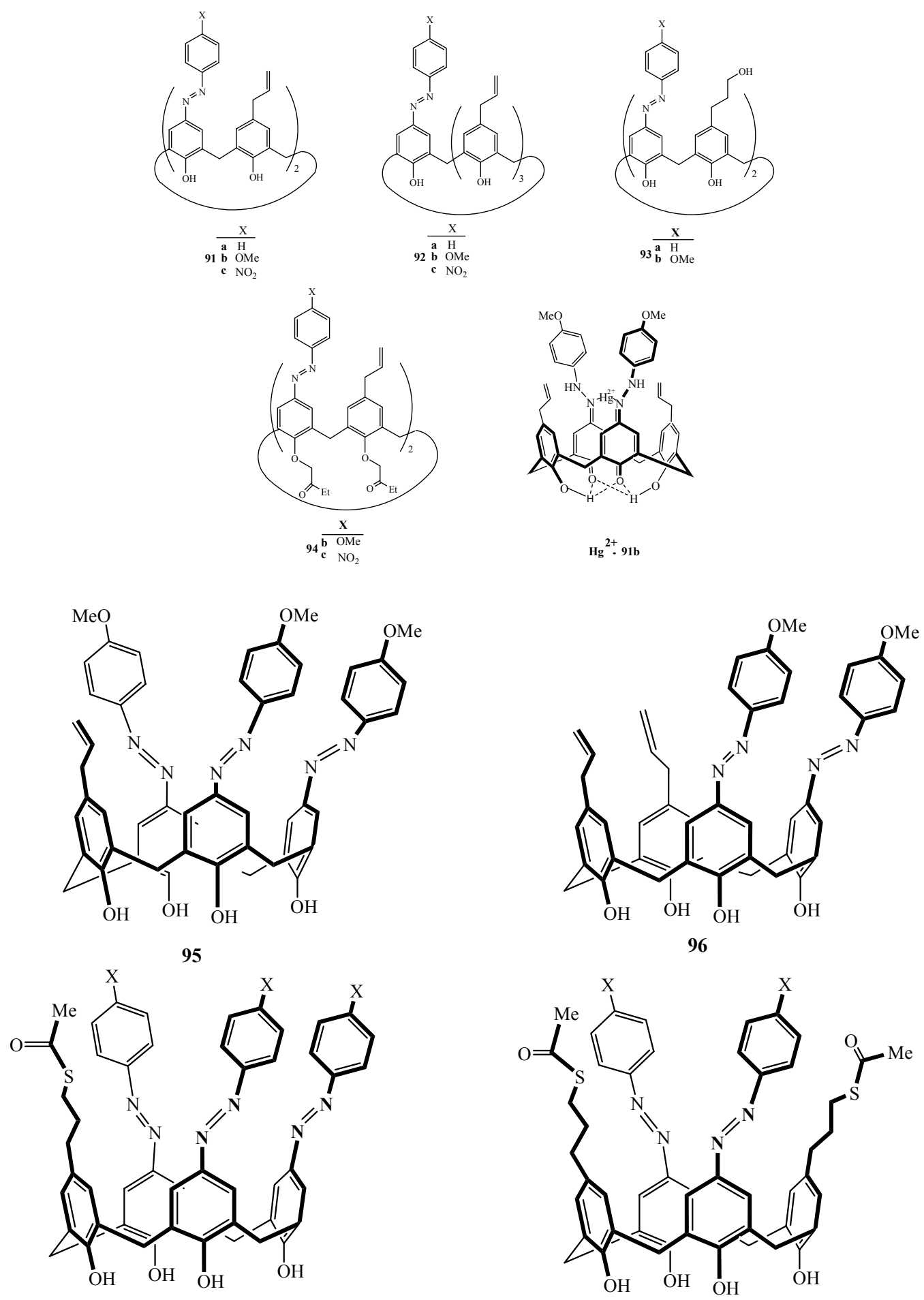

$97_{\text {b } \mathrm{H}}^{\mathrm{H} \text { OMe }}$

$\frac{\mathrm{X}}{98_{\text {b }}^{\text {a } \mathrm{OMe}}}$ 


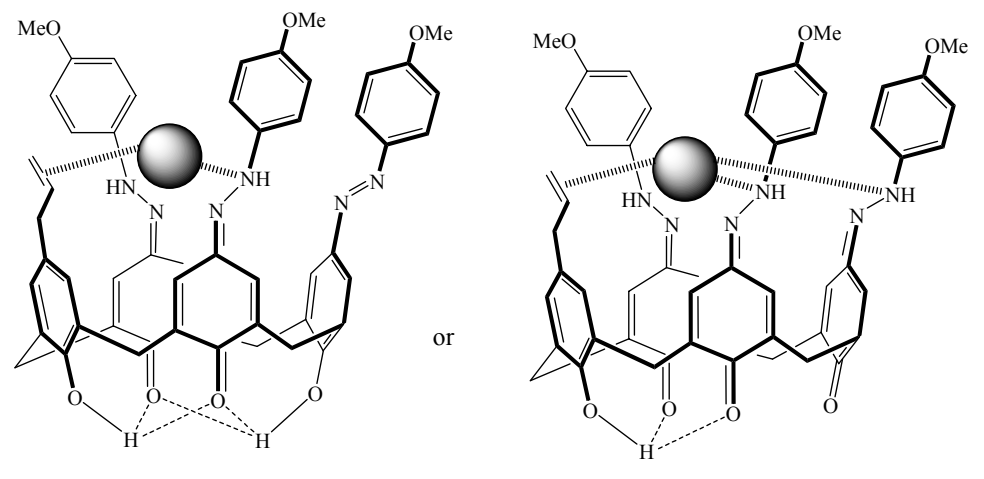

$\mathrm{Hg}^{2+} \cdot 95$

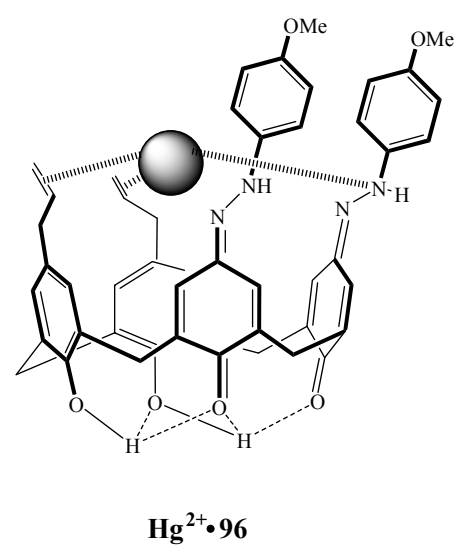

Q $\mathbf{H g}^{2+}$

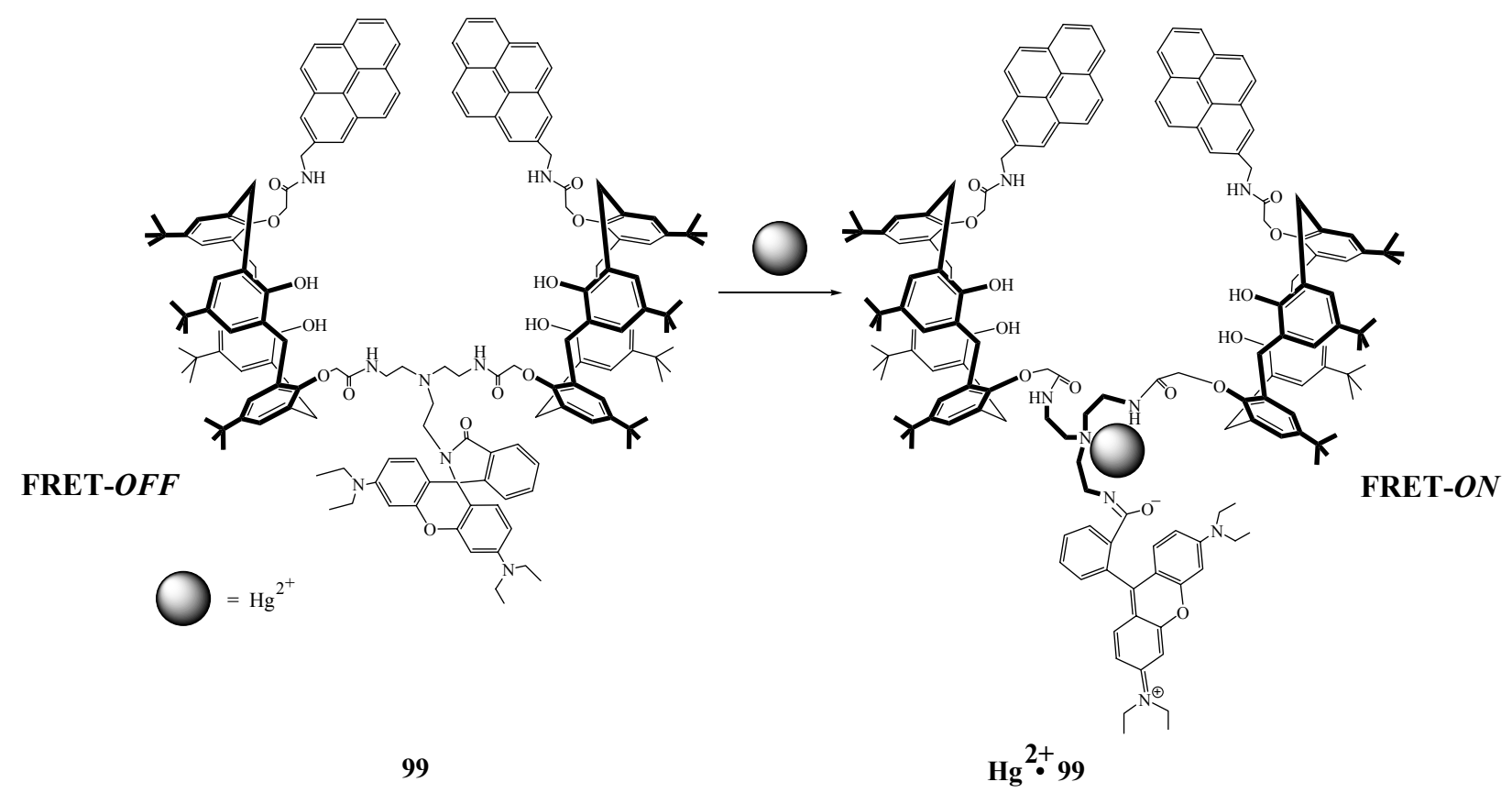

\section{Scheme 9}

\section{Conclusions and future outlook}

The above review, albeit describing only selected examples, sheds some light on the chemistry of calixarene metal complexes. This field of science develops rapidly due to promising properties of such complexes in chemistry as well as in other research areas; ${ }^{148-154}$ here their use as sensors for metal ions ${ }^{26,27}$ and as catalysts ${ }^{22}$ deserves a special attention. One should point out formation of calixarene complexes with lanthanides ${ }^{155-157}$ and actinides ${ }^{158-160}$ in view of the importance of radioactive waste disposal for the environmental protection. Due to the technical progress, one 
may expect that the work concerning complexation of calixarenes with metal ions will develop so from the theoretical and practical viewpoints.

\section{Acknowledgements}

The support of Polish Science Foundation (Grant 4T09 CO3032) is gratefully acknowledged.

\section{References}

1. Oshovsky, G. V; Reinhoudt, D. N.; Verboom, W. Angew. Chem. Int. Ed. 2007, 42, 2366.

2. Rebek, Jr., J. Chem. Commun. 2007, 2777.

3. Rudkevich, D. M. Eur. J. Org. Chem. 2007, 3255.

4. Biros, S. M.; Rebek, Jr. J. Chem. Soc. Rev. 2007, 36, 93.

5. Balasubramanian, R.; Kwon, Y.-G.; Wei, A. J. Mater. Chem. 2007, 17, 105.

6. Nakazawa, J.; Mizuki, M.; Shimazaki, Y.; Tani, F.; Naruta, Y. Org. Lett. 2006, 8, 4275.

7. Xu, S.; Podoprygorina G.; Böhmer V.; Ding, Z.; Rooney, P.; Rangan Ch.; Mittler S. Org. Biomol. Chem. 2007, 5, 558.

8. Liu, Y.; Guo, D.-S.; Zhang, H.-Y.; Ding, F.; Chen, K.; Song H.-B. Chem. Eur. J. 2007, 13, 466.

9. Organo, V. G.; Rudkevich, D. M. Chem. Commun. 2007, 3891.

10. Dalgarno, S. J.; Cave, G. W. V.; Atwood, J. L. Angew. Chem. Int. Ed. 2006, 45, 570.

11. Pirondini, L.; Dalcanale, E. Chem. Soc. Rev. 2007, 36, 695.

12. Zhang, D.; Cao, X.; Purkiss, D. W.; Bartsch, R. A. Org. Biomol. Chem. 2007,5, 1251.

13. Zhou, H,; Liu. D.; Gega, J.; Surowiec, K.; Purkiss, D. W.; Bartsch, R. A. Org. Biomol. Chem. 2007, 5, 324.

14. Sieffert, N,; Wipff, G. J. Phys. Chem. 2006, 110A, 1106.

15. Baldini, L.; Casnati, A.; Sansone, F.; Ungaro, R. Chem. Soc. Rev. 2007, 36, 254.

16. Åhman, A.; Nissinen, M. Chem. Commun. 2006, 1209.

17. Lyskawa, J.; Sallé, M.; Balandier, J.-Y.; Le Derf, F.; Levillain, E.; Allain, M.; Viel, P.; Palacin, S. Chem. Commun. 2006, 2233.

18. Zhou, H.; Surowiec, K.; Purkiss, D. W.; Bartsch, R. A. Org. Biomol. Chem. 2006, 4, 1104.

19. Sémeril, D.; Jeunesse, C.; Matt, D.; Toupet, L. Angew. Chem. Int. Ed. 2006, 45, 5810.

20. Menozzi, E.; Busi, M.; Massera, Ch.; Ugozzoli, F.; Zuccaccia, D.; Macchioni, A.; Dalcanale, E. J. Org. Chem. 2006, 71, 2617.

21. Redshaw, C.; Rowan, M. A.; Warford, L.; Homden, D. M.; Arbaoui, A.; Elsegood, M. R. J.; Dale, S. H.; Yamato, T.; Casas, C. P.; Matsui, S.; Matsuura S. Chem. Eur. J. 2007, 13, 1090.

22. Frediani, M.; Sémeril, D.; Comucci, A.; Bettucci, L.; Frediani, P.; Rosi, L.; Matt, D.; Toupet, L.; Kaminsky, W. Macromol. Chem. Phys. 2007, 208, 938. 
23. Coquière, D.; Marrot, J.; Reinaud, O. Chem. Commun. 2006, 3924.

24. Ji, H.-F.; Yang, Y.; Xu, X.; Brown, G. Org. Biomol. Chem.2006, 4, 770.

25. Chen, L.; Zhang, J.; Zhao, W.; He, X.; Liu. Y. J. Electroanal. Chem. 2006, 589, 106.

26. Souchon, V.; Leray, I.; Valeur, B. Chem. Commun. 2006, 4224.

27. Mikulášek , L.; Grüner, B.; Danila, C.; Böhmer, V.; Čáslavský, J.; Selucký, P. Chem. Commun. 2006, 4001.

28. Lee, M. H.; Quang, D. T.; Jung, H. S.; Yoon, J.; Lee, Ch.-H.; Kim, J. S. J. Org. Chem. 2007, $72,4242$.

29. Morel, J.-P.; Morel-Desrosiers, N. Org. Biomol. Chem. 2006, 4, 462.

30. Eggert, J. P. W.; Harrowfield, J. M.; Lüning, U.; Skelton, B. W.; White, A. H. Polyhedron 2006, 25, 910 .

31. Sansone, F.; Fontanella, M.; Casnati, A.; Ungaro, R.; Böhmer, V.; Saadioui, M.; Liger, K.; Dozol, J.-F. Tetrahedron 2006, 62, 6749.

32. Mikulášek, L.; Grüner, B.; Dordea, C.; Rudzevich, V.; Böhmer, V.; Haddaoui, J.; HubscherBruder, V.; Arnaud-Neu, F.; Č́slavský, J.; Selucký, P. Eur. J. Org. Chem. 2007, 4772.

33. Sliwa, W. ARKIVOC 2006, (v), 137.

34. Sliwa, W.; Dondela. B. ARKIVOC 2007, (ii), 201.

35. Sliwa, W.; Peszke, J. Mini-Reviews in Org. Chem. 2007, 125.

36. Sliwa, W.; Matusiak, G.; Deska, M. Heterocycles 2002, 57, 2179.

37. Sliwa, W.; Deska, M. Khim. Get. Soedin. 2002, 740.

38. Sliwa, W.; Peszke, J. Heterocycles 2007, 71, 1685.

39. Sliwa, W. Khim. Get. Soedin. 2004, 805.

40. Sliwa, W.; Zujewska, T.; Bachowska, B. Polish. J. Chem. 2003, 77, 1079.

41. Sliwa, W. Heterocycles 2002, 57, 169.

42. Sliwa, W. J. Inclusion Phenom. Macrocycl. Chem. 2005, 52, 13.

43. Sliwa, W. Croat. Chem. Acta. 2002, 75, 131.

44. Oueslati, I.; Thuéry, P.; Shkurenko, O.; Suwinska, K.; Harrowfield, J.M.; Abidi, R.; Vicens, J. Tetrahedron, 2007, 63, 62.

45. Rouis, A.; Mlika, R.; Davenas, J.; Ben Ouada, H.; Bonnamour, I.; Jaffrezic, N. J. Electroanal. Chem. 2007, 601, 29.

46. Quang, D. T.; Jung H. S.; Yoon, J. H.; Lee, S. Y.; Kim, J. S. Bull. Korean. Chem. Soc. 2007, $28,682$.

47. Canpolat, E. C.; Sar, E.; Coskun, N. Y.; Cankurtaran, H. Electroanalysis 2007, 19, 1109.

48. Gembus, A.; Corzilius, B.; Eichel, R.-A.; Dinse, K.-P.; Immel, S.; Stumm, D.; Flauaus, M.; Plenio, H. J. Phys. Chem. 2006, 110B, 15012.

49. Fox, O. D.; Cookson, J.; Wilkinson, E. J. S.; Drew, M. G. B.; MacLean, E. J.; Teat, S. J.; Beer, P. D. J. Am. Chem. Soc. 2006, 128, 6990.

50. Creaven, B. S.; Gernon, T. L.; McCormac, T.; McGinley, J.; Moore, A.-M.; Toftlund, H. Inorg. Chim. Acta 2005, 358, 2661. 
51. Halouani, H.; Dumazet-Bonnamour, I.; Perrin, M.; Lamartine, R. J. Org. Chem. 2004, 69, 6521.

52. Psychogios, N.; Regnouf-de-Vains, J.-B.; Stoeckli-Evans, H. M. Eur. J. Inorg. Chem. 2004, 2514.

53. Kumar, A.; Ali, A.; Rao, C.P. J. Photochem. Photobiol. A 2006, 177, 164.

54. Shahgaldian, P.; Pieles, U.; Hegner, M. Langmuir 2005, 21, 6503.

55. Li, S.-Y.; Zheng, Q.-Y.; Chen, C.-F. ; Huang, Z.T. Tetrahedron Asymm. 2005, 16, 2816.

56. Konrad, S.; Bolte, M.; Näther, C.; Lüning, U. Eur. J. Org. Chem. 2006, 4717.

57. Eggert, J. P. W.; Harrowfield,J.; Lüning, U.; Skelton, B. W.; White, A. H.; Löffler, F.; Konrad, S. Eur. J. Org. Chem. 2005, 1348.

58. Konrad, S.; Näther, C.; Lüning, U. Eur. J. Org. Chem. 2005, 2330.

59. Lüning, U.; Fahrenkrug, Eur. J. Org. Chem. 2006, 916.

60. Reinaud, O.; Le Mest, Y.; Jabin, I. in Calixarenes Enter The Nanoworld, Eds: Harrowfield, J.; Vicens, J.; Springer, Dordrecht, Holland, 2006, ch. 13, in press.

61. Le Poul, N.; Campion, M.; Douziech, B.; Rondelez, Y.; Le Clainche, L.; Reinaud, O.; Le Mest, Y. J. Am. Chem. Soc. 2007, 129, 8801.

62. Le Poul, N.; Campion, M.; Izzet, G.; Douziech, B.; Reinaud, O.; Le Mest, Y. J. Am. Chem. Soc. 2005, 127, 5280.

63. Izzet, G.; Zeng, X.; Akdas, H.; Marrot, J.; Reinaud, O. Chem. Commun. 2007, 810.

64. Zeng, X.; Coquière, D.; Alenda, A.; Garrier, E.; Prangé, T.; Li, Y.; Reinaud, O.; Jabin, I. Chem. Eur. J. 2006, 12, 6393.

65. Izzet, G.; Akdas, H.; Hucher, N.; Giorgi, M.; Prangé, T.; Reinaud, O. Inorg. Chem. 2006, 45, 1069.

66. Izzet, G.; Frapart, Y. M.; Prangé, T.; Provost, K.; Michalowicz, A,; Reinaud, O. Inorg. Chem. 2005, 44, 9743.

67. Izzet, G.; Douziech, B.; Prangé, T.; Tomas, A.; Jabin, I.; Le Mest, Y.; Reinaud, O. Proc. Natl. Acad. Sci. U. S. A. 2005, 102, 6831.

68. Darbost, U.; Rager, M.-N.; Petit, S.; Jabin. I.; Reinaud, O. J. Am. Chem. Soc. 2005, 127, 8517.

69. Wang, L.; Zhao, B.-T.; Ye, B.-X. Electroanalysis 2007, 19, 923.

70. Hu, X.; Li, Y.; Yang, H.; Luo, Y. Tetrahedron Lett. 2006, 47, 7463.

71. Laugel, G.; Graf, E.; Hosseini, M. W.; Planeix, J.-M.; Kyritsakas, N. New. J. Chem. 2006, $30,1340$.

72. Konishi, H.; Takahashi, K.; Nakamura, M.; Sakamoto, H.; Kimura, K. J. Inclusion Phenom. Macrocycl. Chem. 2006, 54, 147.

73. Lee, S. H.; Kim, S. H.; Kim, S. K.; Jung, J. H.; Kim, J. S. J. Org. Chem. 2005, 70, 9288.

74. Zeng, X.; Sun, H.; Chen, L.; Leng, X.; Xu, F.; Li, Q.; He, X.; Zhang, W.; Zhang, Z.-Z. Org. Biomol. Chem. 2003, 1, 1073.

75. Csokai, V.; Grün, A.; Balázs, B.; Simon, A.; Tóth, G.; Bitter, I. Tetrahedron 2006, 62, 10215. 
76. Szigeti, Zs.; Malon, A.; Vigassy, T.; Csokai, V.; Grün, A.; Wygladacz, K.; Ye, N.; Xu, Ch.; Bitter, I.; Rathore, R.; Bakker, E.; Pretsch, E. Anal. Chim. Acta 2006, 572, 1.

77. Brown, P.O.; Enright, G.D.; Ripmeester, J. A. Chem. Asian J. 2006, 1, 529.

78. Brown, P. O.; Udachin, K. A.; Enright, G. D.; Ripmeester, J. A. Chem. Commun. 2005, 4402.

79. Nabeshima, T.; Saiki, T.; Iwabuchi, J.; Akine, S. J. Am. Chem. Soc. 2005, 127, 5507.

80. Enright, G. D.; Udachin, K. A.; Ripmeester, J. A. Chem. Commun. 2004, 1360.

81. Wong, M. S.; Xia, P. F.; Lo, P. K.; Sun, X. H.; Wong, W. Y.; Shuang, S. J. Org. Chem. 2006, 71, 940.

82. Puddephatt, R. J. Can. J. Chem. 2006, 84, 1505.

83. Eisler, D. J.; Puddephatt, R. J. Inorg. Chem. 2006, 45, 7295.

84. Eisler, D. J.; Puddephatt, R. J. J. Cryst. Growth Des. 2005, 5, 57.

85. Eisler, D. J.; Puddephatt, R. J. Inorg. Chem. 2005, 44, 4666.

86. Jeunesse, C.; Armspach, D.; Matt, D. Chem. Commun. 2005, 5603.

87. Otero, R.; Rosei, F.; Besenbacher, F. Annu. Rev. Phys. Chem. 2006, 57, 497.

88. Swarbrick, J. C.; Ben Taylor, J.; O’Shea, J. N. Appl, Surf. Sci. 2006, 252, 5622.

89. Grill, L.; Stass, I.; Rieder, K. H.; Moresco, F. Surf. Sci. 2006, 600, L143.

90. Xu, W.; Dong, M.; Vázquez-Campos, S.; Gersen, H.; Laegsgaard, E, Stensgaard, I.; CregoCalama, M.; Reinhoudt, D. N.; Linderoth, T. R.; Besenbacher, F. J. Am. Chem. Soc. 2007, 129, 10624.

91. Xu, W.; Dong, M.; Gersen, H.; Rauls, E.; Vázquez-Campos, S.; Crego-Calama, M.; Reinhoudt, D. N.; Stensgaard, I.; Laegsgaard, E.; Linderoth, T. R.; Besenbacher, F. Small 2007, 3, 854 .

92. Gersen, H.; Schaub, R.; Xu, W.; Stensgaard, I.; Laegsgaard, E.; Linderoth, T. R.; Besenbacher, F.; Nazeeruddin, Md. K.; Graetzel, M. Appl. Phys. Lett. 2006, 89, 264102.

93. Gupta, V. K.; Goyal, R. N.; Al Khayat, M.; Kumar. P.; Bachheti, N. Talanta 2006, 69, 1149.

94. Coquière, D.; Marrot, J.; Reinaud, O. Org. Lett. 2007, 9, 3271.

95. Cacciapaglia, R.; Casnati, A.; Mandolini, L.; Reinhoudt, D. N.; Salvio, R.; Sartori, A.; Ungaro, R. Inorg. Chim. Acta. 2007, 360, 981.

96. Arnott, G.; Hunter, R. Tetrahedron 2006, 62, 992.

97. Danil de Namor, A. F.; Chaaban, J. K.; Abbas, I. J. Phys. Chem A. 2006, 110A, 9575.

98. Danil de Namor, A. F.; Chahine, S.; Castellano, E. E.; Piro, O.E. J. Phys. Chem. 2005, 109A, 6743.

99. Artificial Enzymes, Ed.: Breslow, R., Wiley-VCH, Weinheim 2005.

100.Bakirci, H.; Koner, A. L.; Schwarzlose, T.; Nau, W. M. Chem. Eur. J. 2006, 12, 4799.

101.Bakirci, H.; Nau, W. M.; Adv. Funct. Mater. 2006, 16, 237.

102.Bakirci, H.; Koner, A. L.; Dickman, M. H.; Kortz, U.; Nau, W. M. Angew. Chem. Int. Ed. 2006, 45, 7400 .

103.Bakirci, H.; Koner, A. L.; Nau, W. M. J. Org. Chem. 2005, 70, 9960.

104.Parkin, G. Chem. Rev. 2004, 104, 699. 
105.Darbost, U.; Sénèque, O.; Li, Y.; Bertho, G.; Marrot, J.; Rager, M.-N.; Reinaud, O.; Jabin, I. Chem. Eur. J. 2007, 13, 2078.

106.Sénèque, O.; Rager, M.-N.; Giorgi, M.; Prangé, T.; Tomas, A.; Reinaud, O. J. Am. Chem. Soc. 2005, 127, 14833.

107.Le Gac, S.; Marrot, J.; Reinaud, O.; Jabin, I. Angew. Chem. Int. Ed. 2006, 45, 3123.

108.Darbost, U.; Giorgi, M.; Hucher, N.; Jabin, I.; Reinaud, O. Supramol. Chem. 2005, 17, 243.

109.Garrier, E.; Le Gac, S.; Jabin, I. Tetrahedron: Asymmetry 2005, 16, 3767.

110.Darbost, U.; Zeng, X.; Giorgi, M.; Jabin, I. J. Org. Chem. 2005, 70, 10552.

111.Bukhaltsev, E.; Frish, L.; Cohen, Y.; Vigalok, A. Org. Lett. 2005, 7, 5123.

112.Cohen, Y.; Frish, L.; Avram, L. Angew. Chem. Int. Ed. 2005, 44, 520.

113.Kotzen, N.; Goldberg, I.; Vigalok, A. Inorg. Chem. Commun. 2005, 8, 1028.

114.Beringhelli, T.; D’Alfonso, G.; Maggioni, D.; Mercandelli, P.; Sironi, A. Chem. Eur. J. 2005, 11,650 .

115.Honeychurch, K. C.; Hart, J. P.; Cowell, D. C.; Arrigan, D. W. M. Electroanalysis 2002, 14, 177.

116.Liu, Y.; Guo, D. S.; Zhang, H.-V.; Ma, Y.-H.; Yang, E.-C. J. Phys. Chem. 2006, 110B, 3428.

117.Liu, Y.; Ma, Y.-H.; Chen, Y.; Guo, D.-S.; Li, Q. J. Org. Chem. 2006, 71, 6468.

118.Clark, T. E.; Makha, M.; Raston, C. L.; Sobolev, A. N. Dalton Trans. 2006, 5449.

119.Garozzo, D.; Gattuso, G.; Notti, A.; Pappalardo, A.; Pappalardo, S.; Parisi, M.F.; Perez, M.; Pisagatti, I. Angew. Chem. Int. Ed. 2005, 44, 4892.

120.Danil de Namor, A. F.; Zegarra-Fernandez, K. J. Phys. Chem. 2007, 111B, 7321.

121.Dong, H.; Zheng, H.; Lin, L.;Ye, B. Sensors and Actuators 2006, B115, 303.

122. Benounis, M.; Jaffrezic-Renault, N.; Halouani, H.; Lamartine, R.; Dumazet-Bonnamour, I. Materials Sci. and Engin. 2006, C26, 364.

123.Rouis, A.; Mlika, R.; Dridi, C.; Davenas, J.; Ben Ouada, H.; Halouani, H.; Bonnamour, I.; Jaffrezic, N. Materials Sci. Engin. 2006, C26, 247.

124.Ben Othman, A.; Lee, J. W.; Wu, J.-S.; Kim, J. S.; Abidi, R.; Thuéry, P.; Strub, J. M.; Van Dorsselaer, A.; Vicens, J. J. Org. Chem. 2007, 72, 7634.

125.Danil de Namor, A. F.;Chahine, S.; Castellano, E. E.; Piro, O. E.; Jenkins, H. D. B. Chem. Commun. 2005, 3844.

126.Schazmann, B.; McMahon, G.; Nolan, K.; Diamond, D. Supramol. Chem. 2005, 17, 393.

127.Wong, M. S.; Xia, P. F.; Zhang, X. L.; Lo, P. K.; Cheng, Y.-K.; Yeung, K.-T.; Guo, X.; Shuang, S. J. Org. Chem. 2005, 70, 2816.

128. Métivier, R.; Leray, I.; Lebeau, B.; Valeur, B. J. Mater. Chem. 2005, 15, 2965.

129. Danil de Namor, A. F.;Chahine, S.; Castellano, E. E.; Piro, O. E. J. Phys. Chem. 2004, 108B, 11384.

130.Danil de Namor, A. F.;Chahine, S. J. Phys. Chem. 2005, 109B, 18096.

131.Kao, T.-L.; Wang, Ch.-Ch.; Pan, Y.-T.; Shiao, Y.-J.; Yen, J.-Y.; Shu, C.-M.; Lee, G.-H.; Peng, S.-M.; Chung, W.-S. J. Org. Chem. 2005, 70, 2912. 
132.Halouani, H.; Dumazet-Bonnamour, I.; Lamartine, R. Tetrahedron Lett. 2002, 43, 3785.

133.Ho, I.-T.; Lee, G.-H.; Chung, W.-S. J. Org. Chem. 2007, 72, 2434.

134.Wu, J.-S.; Hwang, I.-C.; Kim, K. S.; Kim, J. S. Org. Lett. 2007, 9, 907.

135.Avirah, R. R.; Jyothish, K.; Ramaiah, D. Org. Lett. 2007, 9, 121.

136.Zheng, H.; Qian, Z.-H.; Xu, L., Yuan, F.-F.; Lan, L.-D.; Xu, J.-G. Org. Lett. 2006, 8, 859.

137.Zhu, X. J.; Fu, S. T.; Wong, W. K.; Guo, H. P.; Wong, W. Y. Angew. Chem. Int. Ed. 2006, 45,3150 .

138.Wang, J. B.; Qian, X. F.; Cui, J. N. J. Org. Chem. 2006, 71, 4308.

139.Xu, Z.; Xiao, Y.; Qian, X.; Cui, J.; Cui, D. Org. Lett. 2005, 7, 889.

140.Schazmann, B.; Alhashimy, N.; Diamond, D. J. Am. Chem. Soc. 2006, 128, 8607.

141.Wu, J.-S.; Zhou, J.-H.; Wang, P.-F.; Zhang, X.-H.; Wu, S.-K. Org. Lett. 2005, 7, 2133.

142.Wu, J.-S.; Liu, W.-M.; Zhuang, X.-Q.; Wang, F.; Wang, P.-F.; Tao, S.-L.; Zhang, X.-H.; Wu, S.-K.; Lee, S.-T. Org. Lett. 2007, 9, 33.

143.Albers, A. E.; Okreglak, V. S.; Chang, C. J. J. Am. Chem. Soc. 2006, 128, 9640.

144.Lee, S. H.; Kim, S. K.; Bok, J. H.; Lee, S. H.; Yoon, J.; Lee, K.; Kim, J. S. Tetrahedron Lett. 2005, 46, 8163.

145.Kim, H. J.; Kim, S. K.; Lee, J. Y.; Kim, J. S. J. Org. Chem. 2006, 71, 6611.

146.Kim, S. K.; Kim, S. H.; Kim, H. Y.; Lee, S. H.; Lee, S. W.; Ko, J.; Bartsch, R. A.; Kim, J. S. Inorg. Chem. 2005, 44, 7866.

147.Yang, Y.-K.; Yook, K.-J.; Tae, J. J. Am. Chem. Soc. 2005, 127, 16760.

148.Colasson, B.; Save, M.; Milko, P.; Roithová, J.; Schröder, D.; Reinaud, O. Org. Lett. 2007, 9, 4987.

149.Sánchez, A.; Jiménez, R.; Ternero, F.; Mesa, R.; Piñero, C. A.; Muriel, F.; Lopez-Cornejo, P. J. Phys. Chem. 2007, 111 B, 10697.

150. Sémeril, D.; Lejeune, M.; Matt, D. New. J. Chem. 2007, 31, 502.

151.Chang, K.-C.; Su, I.-H.; Senthilvelan, A.; Chung, W.-S. Org. Lett. 2007, 9, 3363.

152.Limberg, Ch. Eur. J. Inorg. Chem. 2007, 3303.

153.Dalgarno, S. J.; Power, N. P.; Atwood, J. L. Chem. Commun. 2007, 3447.

154. Valeur, B.; Leray, I. Inorg. Chim. Acta 2007, 360, 765.

155. Makha, M.; Alias, Y.; Raston, C. L.; Sobolev, A. N. New J. Chem. 2007, 31, 662.

156.Gottfriedsen, J.; Hagner, R.; Spoida, M.; Suchorski, Y. Eur. J. Inorg. Chem. 2007, 2288.

157.Puntus, L.N.; Chauvin, A.-S.; Varbanov, S.; Bünzli, J.-C. G. Eur. J. Inorg. Chem. 2007, 2315.

158.Salmon, L.; Thuéry, P.; Asfari, Z.; Ephritikhine, M. Dalton Trans. 2006, 3006.

159.Jain, V. K.; Pandya, R. A.; Pillai, S. G.; Shrivastav, P. S. Talanta 2006, 70, 257.

160.Salmon, L.; Thuéry, P.; Asfari, Z.; Ephritikhine, M. Chem. Commun. 2006, 856. 


\section{Authors' biographical data}

\section{Wanda Śliwa}

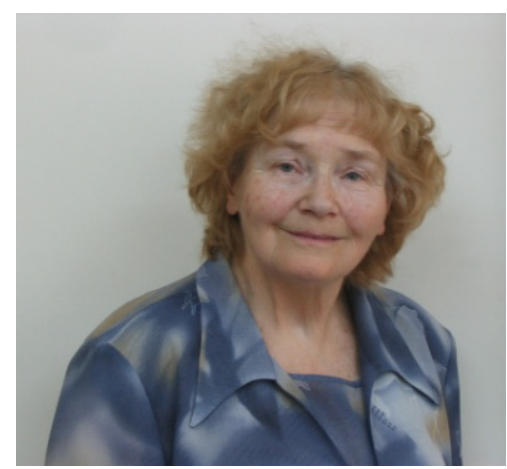

Wanda Śliwa graduated from Wrocław Polytechnical University, Poland, she received there her M.Sc. and Ph.D. degrees. She worked at this University as an Assistant Professor, and then as an Associate Professor. After a year of research (1973/74) at Université Paul Sabatier à Toulouse, France, she moved to Jan Długosz University (formerly Pedagogical University) of Częstochowa, Poland. She is Professor of Chemistry since 1990, has been a Vice-Rector, a Head of Organic Chemistry Department and Director of Institute of Chemistry at this University. She works at the Institute of Chemistry and Environmental Protection of Jan Długosz University of Częstochowa, her research interests concern azaaromatic compounds and supramolecular chemistry.

\section{Malgorzata Deska}

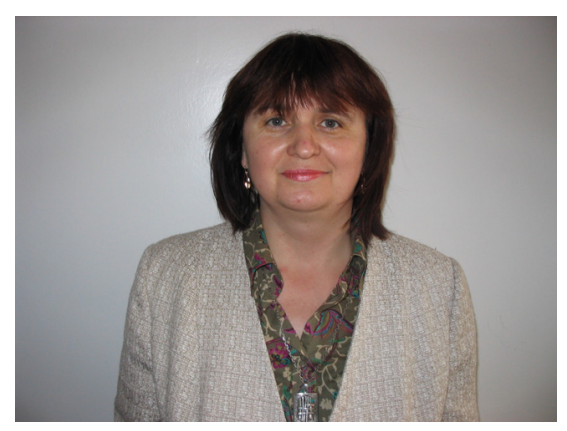

Malgorzata Deska graduated from Pedagogical University of Częstochowa, Poland, she received there M.Sc. degree in 1990. Since this time she works at Jan Długosz University (formerly Pedagogical University) of Częstochowa in Organic Chemistry Department. In 2004 she obtained the Sc.D. at Technical University of Krakow, the doctor thesis concerned physicochemical properties of diazaphenanthrenes. The research interests of Dr Malgorzata Deska are connected with chemistry of heterocyclic compounds and cyclodextrins. 